\title{
EKSPEKTASI INFLASI DI MASA KRISIS
}

\author{
Gantiah Wuryandani dan Reza Anglingkusumo*)
}

Persepsi pelaku ekonomi terhadap perkerbangan perekonomian termasuk inflasi cendenung bentbah sepanjang krisis moneter. Sehingga proses perbentukan ekpektasi inflasi pelaku ekonomi juga berbeda antara sebelum dan sepanjang krisis . Oleh karena itu, perelitian mengenai penbahan perilaku ekspektasi inflasi masyarakat di masa krisis, perlu menjadi agenda taktis dalam rangka mengupayakan efektifitas dan efisiensi pengendalian moneter. Berdasarkan hasil penelitian ini diharadkan dapat diperoleh suatu bendmark untuk mengukur ekspektasi inflasi dimasa mendatang sebagai arahan bagi pelaksanaan kebijakan moneter.

Hasil penelitian menbuktikan adarya "expectation loop" calam perbentukan laju inflasi dan adanya proses badkward maupan formard looking oleh pelaku ekonomi dalam menbentuk ekspektasi inflasi dimasa krisis. Metooblogi yang digunakan adklah estimasi liniear sederhana untuk memperoleh taksiran ekspektasi cari masing-masing variabel penbentuk eksceltasi inflasi. Variabel-variabel terseat acklah: (1) perganch laju inflasi historis terhackp tekanan inflasi yarg sedang berlangsung (inertia), (2) kredibilitas kebijakan disinflasi penerintah, cln (3) ekspektasi kurs nilai tukar Ro/ UDD secara historis, sebagai komponen-komponen penbentuk ekspektasi inflasi badkward looking. Sedangkan ekspektasi inflasi formard looking ditentukan oleh variabel yield spread den forwerd rate Rp/LSD. Taksiran yang diperoleh dengan estimasi linear tersebut selanjutnya di estimasi ulang dengan menggunakan neural network, untuk menangkap dampak bounded rationality para pelaku pasar dalam perbertikan ekspektasi inflasi di masa krisis.

Kesimpulan penelitian menujjkkan bahua cimasa sebelum krisis tercapat ekspektasi inflasi yang mendekati inflasi aktual. Variabel kredibilitas kebijakan disinflasi pererintah menpakan determinan utama dalam perbentukan ekspektasi inflasi, disusul kemolian oleh ekspektasi kurs nilai tukar Bp/twD dan laju inflasi secara historis. Dari hasil similasi ekspektasi inflasi dimasa krisis terlihat bahwa dalambulantajlan tertentu tercapat inoikasi deviasi yang akup signifikan yang menunjkkan adanya ketidakpastian yang sangat tinggi. Ketidakpastian terseat tentama bersumber dari noise, seperti fenomena panic buying di bulan Januari 1998 dan gejolak yang tidkk terdga pada harga Senbako di bulan Juli 1998. Hal ini selanjitrya menujjkkan bahwa tekanan inflasi karena meningkatrya gejolak sosial politik di bulan April dan Mei 1998 telah sepenuhnya diantisipasi oleh pelaku ekonomi. Demikian pula dengan gejolak harga Senbako di bulan Agustus dan Septenber 1998.

Dari berbagai pengujian dalam paper ini disarankan ctoritas moneter perlu memilah-milah faktor-faktor penbentuk inflasi dari sisi moneter maupn non moneter. Disaping itu perlu pula ditetadkan target band inflasi moneter berikt leading indicator penantaunya, sebagai suatu langkah untuk mengendalikan inflasi secara preentive oleh ctoritas moneter. Dalam rangka pengendalian laju inflasi yang lebih disebabkan oleh tekanan stnktural dan noise, ctoritas moneter perlu melakikan koordinasi dengan departenen terkait.

*) Gantiah Wuryandani : Peneliti Ekonomi, Bagian Studi Sektor Riil, UREM-BI

Reza Anglingkusumo : Asisten Peneliti Ekonomi, Bagian Studi Sektor Riil, UREM-BI, email : bigsix@cbn.net.id Penulis mengucapkan terimakasih kepada Perry Warjiyo, Kepala Biro Gubernur - BI, atas kritik dan sarannya, serta Anggito Abimanyu atas komentarnya. 
Pendahuluan

risis moneter telah menempatkan inflasi sebagai salah satu indikator strategis bagi upaya mengeluarkan perekonomian nasional dari resesi yang berkepanjangan.

Sampai saat ini berbagai upaya telah dilakukan pemerintah baik itu melalui pengendalian inflasi dari sisi moneter oleh Bank Indonesia sebagai Otoritas Moneter, maupun kebijakan disinflasi dari sisi penawaran agregat oleh departemen-departemen yang terkait langsung dengan sisi produksi dan distribusi barang-barang konsumen.

Dalam kaitannya dengan kebijakan moneter untuk mengendalikan inflasi, salah satu faktor terpenting bagi efektifitas dan efisiensi pelaksanaannya oleh Bank Indonesia adalah pemahaman mengenai terbentuknya ekspektasi inflasi oleh para pelaku ekonomi. Dengan diperolehnya pemahaman tersebut maka dapat dilakukan taksiran ekpektasi inflasi yang selanjutnya dapat dijadikan sebagai : (1) arahan bagi penentuan target inflasi moneter oleh Bank Indonesia, dan (2) masukan bagi kebijakan disinflasi non-moneter oleh pemerintah c.q. departemen terkait.

Oleh karena itu dalam makalah ini penulis mencoba memetakan proses pembentukan ekspektasi inflasi dengan berargumentasi bahwa ekspektasi inflasi dibentuk oleh ekpektasi backward dan forward looking para pelaku ekonomi ${ }^{1}$. Ekspektasi inflasi backward looking didefinisikan sebagai ekspektasi inflasi yang terbentuk sebagai akibat dari doservasi pelaku ekonomi terhadap dinamika inflasi dimasa lalu. Sedangkan ekspektasi inflasi forward lookking dilain pihak, didefinisikan sebagai ekspektasi inflasi yang terbentuk oleh antisipasi pelaku ekonomi di pasar keuangan domestik dan pasar forward Rp/USD. Dengan mengidentifikasikan ekspektasi inflasi kedepan sebagai proses evaluasi backward dan forward, selanjutnya dihitung suatu taksiran ekspektasi inflasi kedepan.

Berdasarkan pendekatan seperti diatas kedua penulis berargumen bahwa dimasa krisis moneter upaya pengendalian inflasi oleh pemerintah tampaknya telah meredakan ketidakpastian dan menurunkan ekspektasi inflasi para pelaku ekonomi. Terdapat pula indikasi yang kuat bahwa dengan menurunnya ekspektasi inflasi tersebut, maka forward rate Rp/USD di pasar valas pun akan menguat.

Dinamika Inflasi dan Pengendaliannya Sepanjang Krisis Moneter

Kebijakan pengendalian inflasi dimasa krisis menuntut pemerintah untuk mampu mengkondisi penurunan level laju inflasi secara berkesinambungan, mengupayakan adanya

1 Dalam kaitannya dengan pembagian jenis ekspektasi pelaku ekonomi terhadap inflasi, penulis merujuk pada Gordon, Robert J. Macroeconomics. 1994. 
kepastian harga, dan mengatasi gejolak harga. Melihat prasyarat tersebut, maka pembentukan upward spiral ekspektasi inflasi di masa krisis selain disebabkan oleh faktor ekspansi moneter dan pass-through depresiasi nilai tukar Rp/USD, juga disebabkan oleh faktor-faktor yang bersifat struktural dan noise. Oleh karena itu kebijakan pengendalian inflasi di Indonesia harus mempertimbangan kebijakan disisi penawaran disamping kebijakan moneter. Ulasan dibawah ini akan memberi sedikit gambaran mengenai dinamika inflasi IHK dan kebijakan pengendaliannya oleh pemerintah sepanjang krisis moneter.

Pada Grafik 1 dibawah, dapat diamati perkembangan beberapa indikator laju inflasi diluar inflasi IHK, yaitu laju inflasi yang disebabkan oleh tekanan apresiasi USD, laju inflasi yang disebabkan oleh pertumbuhan uang beredar, laju inflasi sisi pemintaan agregat atau underlying inflation, dan sebuah indikator yang disebut indicator of policy severity ${ }^{2}$. Laju inflasi yang disebabkan oleh apresiasi USD ditaksir dengan mengukur pengaruh 4 lags dari perubahan kurs Rp/USD terhadap laju inflasi IHK. Taksiran yang diperoleh kemudian digunakan untuk melakukan in-sample (static) forecast. Hasil yang diperoleh adalah taksiran laju inflasi yang disebabkan oleh persentase perubahan kurs Rp/USD bulanan. Sementara, laju inflasi yang disebabkan oleh uang beredar ditaksir dengan mengukur pengaruh 4 lags dari perubahan bulanan base money terhadap laju inflasi IHK. Sedangkan, underlying inflation diukur sebagai keranjang IHK bulanan yang sudah dipangkas sebesar 17.5\% pada masingmasing tails histogramnya ${ }^{3}$. Selanjutnya, indicator of policy severity adalah selisih antara suku bunga SBI riil dan spread antara suku bunga deposito 1 bulan dan 24 bulan nominal (representasi dalam bentuk nomalized) ${ }^{4}$.

Grafik 1. Perkembangan Beberapa Indikator Inflasi dan Indicator of Policy Severity Sepanjang Krisis Moneter

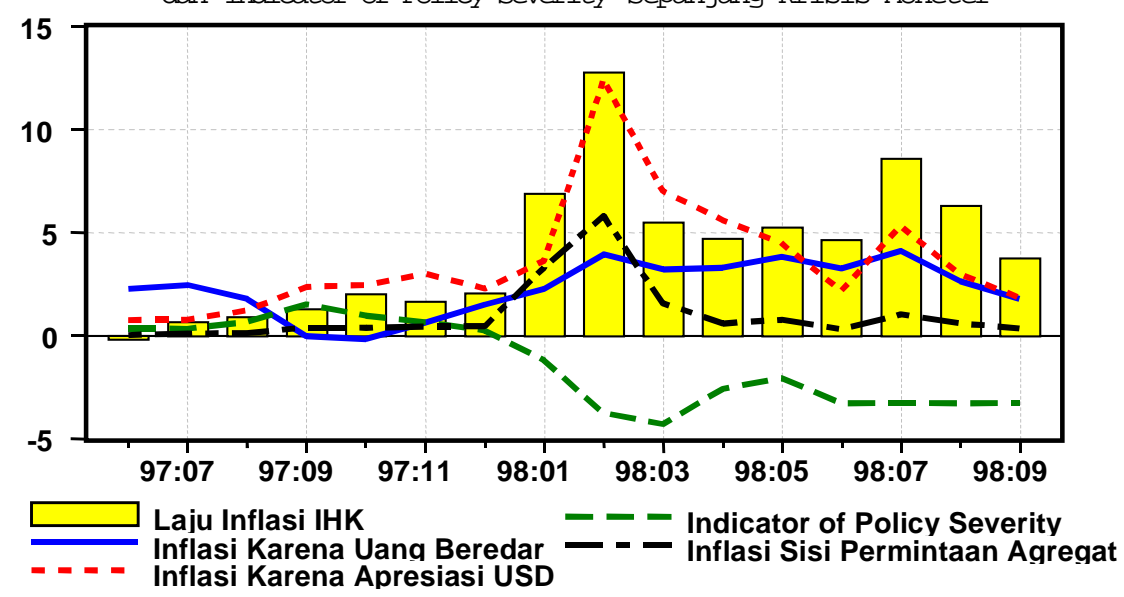

2 Metodologi pengukuran indikator-indikator ini dapat dilihat di Annex 1.

3 Roger, Scott. Measures of Underlying Inflation in New Zealand, 1985 - 1996. RBNZ Discussion Paper, 1997.

4 Indicator of Policy Severity, Bank of Canada. 
Dapat dilihat pada grafik diatas bahwa diawal krisis moneter yaitu pada triwulan IV/1997 laju inflasi karena apresiasi Rp/USD meningkat diatas laju inflasi IHK, yang menandakan menguatnya tekanan first stage passthrough apresiasi USD pada harga barangbarang tradeables. Sementara itu tekanan permintaan agregat yang masih cenderung kuat dalam perekonomian, juga menyumbang pada tekanan inflasi IHK. Di bulan November 1997, seiring dengan diumumannya likuidasi 16 bank, terjadi bank run dalam sistem perbankan yang berakibat tingginya ekspansi moneter dalam perekonomian dan selanjutnya memberi tekanan inflatoir sepanjang triwulan IV / 1997. Dari sisi pasar keuangan, menurunnya grafik indicator of policy severity di triwulan IV/1997 mencerminkan bahwa tekanan inflatoir telah diikuti oleh meningkatnya suku bunga nominal perbankan .

Memasuki triwulan I/1998 tekanan apresiasi kurs USD/Rp pada laju inflasi mencapai puncaknya yang terutama didorong oleh fenomena flight to arrency ${ }^{5}$ dan flight to quality ${ }^{6}$, serta meningkatnya spekulasi terhadap nilai tukar Rp/USD di kedua bulan tersebut. Ekspansi uang beredar juga tampak masih kuat di triwulan I/1998, terutama karena fenomena bank - nun telah semakin meluas di bulan Januari 1998 sebagai akibat menurunnya kepercayaan masyarakat pada sistem perbankan. Selain itu, terdapat pula tekanan musiman di bulan Januari 1998 berupa datangnya bulan Ramadhan dan Hari Raya Idul Fitri. Di bulan Februari 1998, terjadi demand shock, ketika panic buying melanda pasar barang-barang konsumsi. Panic buying ini disebabkan oleh ketidakpastian harga karena adanya gejolak nilai tukar yang dahsyat di bulan Januari 1998. Tingginya ketidakpastian ditambah dengan besarnya jumlah uang yang beredar dalam perekonomian kemudian menjadi agregat demand shock melalui konsumsi. Hal ini terlihat di bulan Februari 1998 ketika inflasi karena tekanan agregat demand meningkat tajam.

Di triwulan II/1998, laju inflasi karena tingginya tekanan apresiasi USD terhadap Rupiah mulai melemah, mencerminkan telah berakhirnya tekanan first stage pass through apresiasi USD terhadap harga barang-barang impor. Beberapa jenis barang dan jasa yang termasuk dalam kategori ini adalah harga bahan-bahan bangunan, harga makanan jadi dengan bahan baku impor, biaya sewa rumah, kenaikan upah disektor informal yang tidak terikat oleh ketentuan UMR, dan biaya jasa angkutan sebagai akibat meningkatnya harga suku cadang. Walaupun demikian, tekanan inflasi karena ekspansi uang beredar tampak

5 Fenomena flight to currency didefinisikan sebagai kegiatan lindung nilai (hedging) yang dilakukan oleh pelaku pasar domestik dengan menukar uang Rp ke USD karena menurunnya tingkat kepercayaan pada mata uang Rupiah.

6 Fenomena flight to quality didefinisikan sebagai kegiatan lindung nilai (hedging) yang dilakukan oleh pelaku pasar domestik dengan mengalihkan simpanan aset yang dimilikinya di bank-bank domestik ke simpanan di bank asing yang dirasa lebih berkualitas. Hal ini dilakukan karena merosotnya tingkat kepercayaan pelaku pasar terhadap kredibilitas bank-bank domestik. 
masih kuat, terutama disebabkan oleh bantuan likuiditas otoritas moneter sebagai the lender of last resort kepada perbankan yang terkena bank nun. Tekanan inflasi moneter tersebut sedikit banyak dapat di off-set oleh menurunnya tekanan permintaan agregat pasca Ramadhan, Lebaran, dan panic buying. Penurunan tekanan permintaan agregat ini selain disebabkan oleh menurunnya konsumsi, juga disebabkan oleh mulai terasanya credit crunch dalam sistem perbankan sehingga dana tidak mengalir ke sektor riil. Bersamaan dengan itu pula otoritas moneter melakukan pengetatan moneter dengan melakukan adjustment tingkat suku bunga policy anchor (SBI) agar sesuai dengan ekspektasi inflasi di pasar keuangan.

Di pertengahan triwulan II/1998 laju inflasi IHK diwarnai pula oleh tekanan inflatoir yang lebih bersifat struktural. Tekanan struktural pertama adalah energy price shock yang disebabkan oleh kebijakan pemerintah menaikkan harga BBM. Tekanan struktural terus meningkat ketika perekonomian memasuki triwulan III/1998, terutama dibulan Juni dan Juli 1998 yang ditandai oleh harga-harga bahan kebutuhan pokok yang melonjak, terutama beras, gula, minyak goreng, dan komoditas derivatifnya. Kenaikan harga beras disebabkan oleh menurunnya kualitas dan kuantitas produksi beras karena mahalnya harga pupuk dan pestisida yang merupakan komoditi impor. Kenaikan harga gula disebabkan oleh dinaikkannya harga perolehan gula di Bulog. Sedangkan kenaikan harga minyak goreng disebabkan oleh berkurangnya pasokan minyak goreng domestik karena CPO banyak terserap ke pasar ekspor. Di bulan Agustus, tekanan inflatoir pada komoditas sembako masih tetap kuat, terutama karena permasalahan disisi distribusi yang diwarnai oleh tindakan spekulatif pelaku pasar. Untuk menurunkan tekanan struktural tadi, sepanjang bulan September 1998 pemerintah telah mencoba berbagai kebijakan proaktif untuk menyelesaikan persoalan-persoalan di sisi distribusi. Tampaknya kebijakan di sisi distribusi tersebut cukup berhasil, terutama dalam kaitannya dengan distribusi beras.

Selain tekanan struktural, dinamika inflasi setelah triwulan I /1998 juga diwamai oleh kuatnya tekanan noise inflation, yaitu gejolak temporer pada harga-harga. Nbise terpenting terjadi di bulan Februari dan Mei 1998. Di bulan Februari demand shock berupa panic buying telah menyebabkan hilangnya berbagai stodk barang dipasaran karena pengusaha retail tidak memperhitungkan panic buying dalam inventory order nya. Di bulan Mei kerusuhan sosial yang melanda 5 kota industri utama di Indonesia menyebabkan terganggunya pasokan barang dengan rusaknya sebagian besar pusat-pusat kegiatan usaha.

Di triwulan II dan III / 1998 laju inflasi yang disebabkan oleh ekspansi moneter tampak mulai menurun sebagai akibat konsistensi otoritas moneter dalam menerapkan tingkat suku bunga tinggi. Upaya tersebut mampu menurunkan laju inflasi secara bertahap seiring dengan ketatnya likuiditas di sektor riil. 
Proses Pembentukan Ekspektasi Inflasi

\section{A. Expectation Loops}

Ekspektasi inflasi menpakan dinamika interaksi antara laju inflasi, ketidakpastian dan gejolak harga. Dihipotesakan bahwa terdapat penubahan rangkaian jalinan interaksi antara laju inflasi, ketidakpastian, dan gejolak harga dalam masa sebelum dan sepanjang krisis. Berikut adblah pengujian dari masing-masing interaksi tersebut.

\section{Loop I : Interaksi antara Gejolak Harga dan Ketidakpastian Harga}

Analisa keterkaitan antara laju inflasi IHK dengan gejolak dan ketidakpastian harga menunjukkan bahwa pembentukan ekspektasi inflasi mengikuti pola tmbal balik yang self-reinforcing (expectation loops). Expectation logps ini diawali dengan adanya gejolak hargaharga yang ditunjukkan oleh conditional variance series inflasi IHK yang mengalami peningkatan karena meningkatnya weighted mean dan standard deviation ${ }^{7}$. Pada grafik 2 dibawah dapat dilihat bahwa pada periode sebelum krisis, pergerakan laju inflasi IHK cenderung berada di seputar kecenderung jangka panjangnya. Dimasa krisis, perilaku ini mengalami perubahan, dimana terlihat deviasi laju inflasi IHK yang cukup besar dari kecenderungannya. Gejolak mulai terlihat di bulan Januari 1998 ketika nilai tukar Rp/ USD terdepresiasi secara besar-besaran. Setelah itu terjadi panic buying yang menyebabkan terjadinya agregat demand shock melalui konsumsi di bulan Februari 1998. Laju inflasi kemudian menurun lebih dari setengahnya di bulan Maret 1998 yang menyebabkan terjadi gejolak harga berikutnya. Di bulan Juli, Agustus, dan September kenaikan harga Sembako

Grafik 2. Laju Inflasi IHK, Gejolak Harga, dan Trend Inflasi IHK (12 MA)

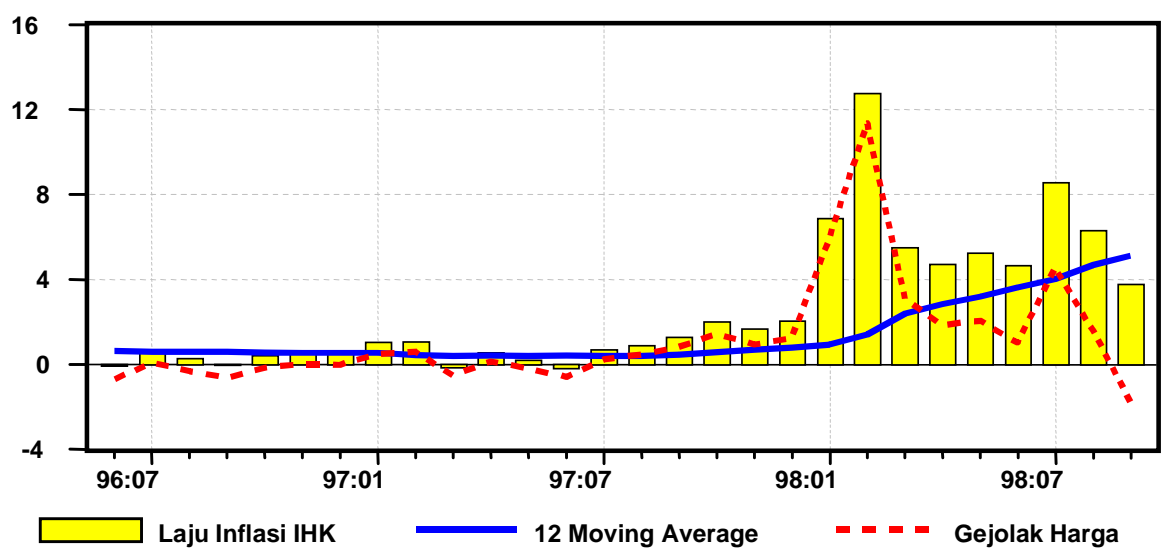

7 Conditional variance diukur sebagai deviasi laju inflasi IHK bulanan terhadap angka inflasi IHK 12 Bulan Moving Average. 
menyumbang pada gejolak harga fase berikutnya sehingga laju inflasi IHK cenderung masih menjauh dari kecenderungan jangka panjangnya.

Peningkatan pada moments pertama dan kedua diatas, kemudian diikuti pula oleh peningkatan moments ketiga (skewness) dan moments keempat (kurtosis). Dengan membandingkan dua histogram pada grafik 3, terlihat bahwa laju inflasi dimasa krisis memiliki nilai kurtosis yang lebih tinggi dari pada sebelum krisis. Hal ini menandakan bahwa laju inflasi dimasa krisis cenderung berada pada rata-rata yang lebih tinggi dengan standar deviasi yang juga tinggi. Sehingga dapat dikatakan bahwa laju inflasi IHK di masa krisis cenderung bergejolak pada tingkat yang inflatoir.

Grafik 3. Frekuensi Distribusi Conditional Variance Series Inflasi IHK Periode 06/1990 - 06/1997 vs. 06/1990 - 09/1998
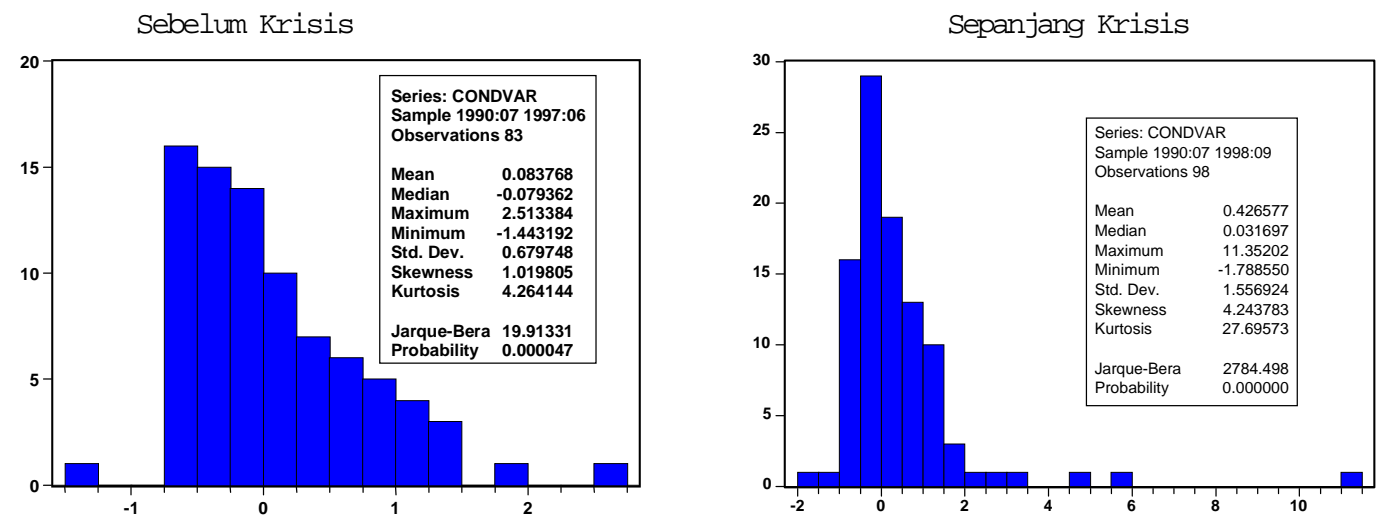

Meningkatnya gejolak inflasi IHK diatas selanjutnya menyebabkan pula meningkatnya ketidapastian laju inflasi $\mathbb{H K}^{8}$. Ketidakpastian laju inflasi IHK ini ditaksir sebagai proses E-GARCH dari persamaan IHK dan unsur konstantanya dan disebut sebagai unconditional variance laju inflasi $\mathbb{H K}^{9}$. Meningkatnya unconditional variance menceminkan ketidakpastian harga (price uncertainty) yang meningkat. Observasi grafis (grafik 4) sepanjang krisis moneter menunjukkan bahwa gejolak harga berjalan searah dengan ketidakpastian harga kecuali pada bulan April 1998 dimana gejolak harga yang cenderung menurun diikuti oleh ketidakpastian yang meningkat .. Penjelasan kualitatif mengenai kejanggalan ini antara lain disebabkan oleh meningkatnya gejolak sosial-politik di berbagai daerah di Indonesia.

8 Kajian serupa dilakukan pula oleh Kearns, Jonathan. Behavior of Inflation. Internal Note, unpublished, RBA.

9 Unconditional variance ditaksir sebagai proses E-GARCH dengan 1 bulan lag dari residu persamaan CPI = Konstan + Residual, dimana CPI adalah laju inflasi bulanan IHK. Untuk referensi dapat dilihat Engle Robert F., dan Ng, K. Victor. Measuring and Testing The Impact of News on Volatility, The Journal of Finance, Vol. XLVIII, No.5, Dec. 1993. Proses serupa dilakukan oleh McTaggart, Doug. The Cost of Inflation in Australia, Proceedings of a Conference, RBA. 
Grafik 4. Gejolak, Ketidakpastian Harga, dan Laju Inflasi IHK Sepanjang Krisis Moneter



Ü̈ Pairwise Granger Causality ${ }^{10}$ mengenai keterkaitan antara gejolak dan ketidakpastian harga menunjukkan bahwa hubungan kausalitas berlangsung dua arah antara gejolak dan ketidakpastian dalam dinamika laju inflasi IHK pada observasi yang memasukkan periode krisis moneter (lihat Tabel 1) . Hal ini bertolak-belakang dengan hasil pengujian pada doservasi yang mengeluarkan bulan-bulan krisis moneter. Sehingga, dapat disimpulkan bahwa terdapat expectation loop antara gejolak dan ketidakpastian, dimana meningkatnya gejolak inflatoir pada laju inflasi IHK akan menyebabkan ketidakpastian harga yang selanjutnya akan menambah pada gejolak inflatoir, dan seterusnya berulang. Adapun besarnya kekuatan hubungan dalam expectation loop antara gejolak dan ketidakpastian ditaksir dengan melakukan regresi linier sederhana antara keduanya ditambah dengan komponen persisten (lag) dari kedua variabel tersebut. Hasil regresi linier menunjukkan bahwa tekanan ketidakpastian harga ke gejolak harga cenderung lebih mendominasi expectation loop, dibandingkan dengan arus balik dari gejolak ke ketidakpastian. Hal ini ditunjukkan oleh lebih besamya persentase adjusted Rsquared dan net-effect dari koefisien pada persamaan (lihat tabel 2) .

10 Metodologi Pairwise Granger Causality dapat ditemui pada Enders, Walter E. Applied Econometrics Time Series, hal. 315 , Granger Causality. 
Tabel 1. Pairwise Granger Causality Test antara Gejolak dan Ketidakpastian Harga

Sampel : 06/1990 - 06/1997 (Diluar Krisis Mbneter)

\begin{tabular}{|c|c|c|c|c|}
\hline Hipotesa Nol & & $\underline{\mathrm{Obs}}$ & F-Stat & Prob. \\
\hline Ketidakpastian & Gejolak & 79 & 0.34 & 0.71 \\
\hline Gejolak & Ketidakpastian & & 0.85 & 0.43 \\
\hline \multicolumn{5}{|c|}{ Sampel : 06/1990 - 09/1998 (Ditambah Krisis Moneter) } \\
\hline Hipotesa Nol & & $\underline{\mathrm{Obs}}$ & F-Stat & Prob. \\
\hline Ketidakpastian & Cejolak & 94 & 6.18 & 0.305 \\
\hline Gejolak & Ketidakpastian & & 5.45 & 0.00585 \\
\hline
\end{tabular}

Tabel 2. Hasil Regresi Linier Kekuatan Pengaruh Antara Gejolak dan Ketidakpastian Harga (Model Persamaan dengan Persistensi)

\section{Variabel Endogen}

Gejolak $\quad$ Ketidakpastian

$\begin{array}{llc}\text { Gejolak } & 0.36(\operatorname{Lag}-1) & 0.85 \\ \text { Ketidakpastian } & 1.01 & -0.35 \text { (Iag }-1) \\ \text { Adj. R-Squared } & 90 \% & 86 \% \\ \text { Net Effect Koefisien } & 1.37 & 0.5\end{array}$

Berdasarkan temuan diatas diperoleh tiga implikasi, yaitu (1) di masa krisis spiral ekspektasi inflasi akan lebih menggelembung jika terdapat ketidakpastian harga , dibandingkan jika spiral diawali oleh gejolak harga, (2) jika ekspektasi diawali oleh gejolak harga belum tentu terjadi penggelembungan laju inflasi, dan (3) ketidakpastian harga merupakan trigger point dalam upaya menghambat spiral inflasi.

\section{Ioop II : Interaksi Antara Ketidakpastian dan Iaju Inflasi}

Self-reinforcing expectation loop yang kedua adalah antara ketidakpastian harga-harga dan laju inflasi. Adanya ketidak pastian harga dimasa krisis menyebabkan para pelaku ekonomi menjadi sulit untuk menentukan harga, sehingga penyesuaian harga lintas industri (relative price adjustment) sulit dilakukan dan cenderung menjadi sangat bervariasi. Dalam ketidakpastian tersebut, pengusaha akan cenderung menimbun barang (commodity hoarding) atau menaikkan harga sehingga mendorong kenaikan laju inflasi lebih lanjut. Kenaikan laju inflasi kemudian akan kembali mempengaruhi ketidakpastian harga sehingga terjadi self-reinforcing loop . 
Hasil uji Granger Causality antara ketidakpastian harga dan laju inflasi memberi konfimasi terhadap pernyataan-pernyataan diatas (lihat tabel 3) .Dapat dilihat bahwa pada periode sebelum krisis moneter, laju inflasi yang tinggi dapat menyebabkan ketidakpastian harga-harga akan tetapi tidak sebaliknya. Hal ini antara lain disebabkan kurang sensitifnya daya beli konsumen terhadap tindakan spekulasi maupun penyesuaian kenaikan harga. Sehingga, ketidakpastian harga menjadi kurang berperan dalam proses looping. Akan tetapi dimasa krisis, terdapat indikasi yang sangat kuat bahwa ketidakpastian harga-harga menyumbang pada tekanan inflasi, dan sebaliknya. Hal ini memberi petunjuk adanya penyesuaian harga keatas yang kurang terkoordinasi secara lintas industri yang berakibat pada kegiatan spekulasi dan kelangkaan barang. Kemudian, seiring dengan meningkatnya laju inflasi terjadi akumulasi ketidakpastian harga yang selanjutnya diterjemahkan menjadi ketidakpastian harga yang berkelanjutan. Spiral yang terjadi kemudian membentuk selfreinforcing loop.

Tabel 3. Pairwise Granger Causality Test antara Laju Inflasi dan Ketidakpastian Harga

Sampel : 06/1990 - 06/1997 (Diluar Krisis Moneter)

\begin{tabular}{|c|c|c|c|c|}
\hline Hipotesa Nol & & $\underline{\mathrm{Obs}}$ & F-Stat & Prob. \\
\hline Ketidakpastian & Laju Inflasi & 83 & 0.186 & 0.83 \\
\hline Iaju Inflasi & Ketidakpastian & & 4.34 & 0.0163 \\
\hline \multicolumn{5}{|c|}{ Sampel : 06/1990 - 09/1998 (Ditambah Krisis Moneter) } \\
\hline Hipotesa Nol & & $\underline{\mathrm{Obs}}$ & F-Stat & Prob. \\
\hline Ketidakpastian & Laju Inflasi & 98 & 9.00 & 0.00027 \\
\hline Iaju Inflasi & Ketidakpastian & & 7.79 & 0.00074 \\
\hline
\end{tabular}

Seperti yang juga telah dilakukan diatas, untuk melihat perbandingan tekanan antara laju inflasi dan ketidakpastian harga-harga dalam expectation loop, dilakukan regresi linier sederhana antara laju inflasi dan ketidakpastian harga, dan sebaliknya. Estimasi persamaan menunjukkan bahwa ketidakpastian harga-harga mendominasi expectation loop antara kedua variabel, dimana net-effet pengaruh kenaikan laju inflasi pada ketidakpastian harga adalah 0.33\% untuk setiap 1\% kenaikan laju inflasi, sebaliknya untuk setiap 1\% kenaikan ketidakpastian harga akan diikuti oleh kenaikan laju inflasi sebesar 1.59\% (lihat tabel 4) . 
Tabel 4. Hasil Regresi Linier Kekuatan Pengaruh Antara Ketidakpastian Harga dan Laju Inflasi (Model Persamaan dengan Persistensi)

\section{Variabel Endogen}

Iaju Inflasi

$0.52(\operatorname{Lag}-1)$

1.07

$98 \%$

1.59

\section{Ketidakpastian}

0.78

$-0.45(\operatorname{Lag}-1)$

$89 \%$

0.33

Implikasi hasil statistik pada loop II ini dalam masa krisis ada tiga, yaitu: (1) ketidakpastian harga-harga akan meningkatkan laju inflasi, (2) laju inflasi yang didorong oleh ketidak pastian harga akan kembali menambah pada ketidakpastian harga, dan seterusnya, sehingga (3) spiral inflasi dapat melambat hanya jika ketidakpastian harga dikurangi.

\section{Interaksi Antara Laju Inflasi dan Gejolak Harga}

Hasil pengujian Pairwise Granger Causality pada bulan-bulan yang memasukkan krisis moneter, menunjukkan bahwa tidak terdapat self reinforcing loop antara laju inflasi dan gejolak harga. Pada observasi yang mengeluarkan krisis moneter terlihat bahwa hanya terdapat hubungan satu arah antara laju inflasi dan gejolak harga (lihat tabel 5) ${ }^{11}$.

Tabel 5. Pairwise Granger Causality Test

antara Laju Inflasi dan Gejolak Harga

Sampel : 06/1990 - 06/1997 (Diluar Krisis Moneter)

$\begin{array}{llrrr}\text { Hipotesa Nol } & & \text { Obs } & \text { F-Stat } & \text { Prob. } \\ \text { Gejolak } & \text { Laju Inflasi } & 79 & 0.37 & 0.69 \\ \text { Laju Inflasi } & \text { Gejolak } & & 2.78 & 0.06\end{array}$

Sampel : 06/1990 - 09/1998 (Ditambah Krisis Moneter)

$\begin{array}{llrrr}\text { Hipotesa Nol } & & \text { Obs } & \text { F-Stat } & \text { Prob. } \\ \text { Gejolak } & \text { Iaju Inflasi } & 94 & 0.71 & 0.49 \\ \text { Laju Inflasi } & \text { Gejolak } & & 0.27 & 0.76\end{array}$

11 Mengingat hasil uji kausalitas yang menolak adanya self reinforcing loop dari inflasi ke gejolak harga dan sebaliknya, maka tidak dilakukan estimasi regresi linier . 
Berdasarkan hasil pengujian-pengujian untuk melihat interaksi antara gejolak harga, ketidakpastian dan laju inflasi diatas, secara umum diperoleh gambaran bahwa proses pembentukan inflasi dalam periode sebelum krisis dan termasuk masa krisis mengalami perubahan. Sebelum terjadi krisis, tidak ditemui adanya self reinforcing expectation loops pembentukan ekspektasi inflasi, sebaliknya dimasa krisis hal tersebut ada (lihat diagram la dan 1b) .

Diagram 1a. Dinamika Ekspektasi Inflasi IHK Sebelum Krisis



Diagram 1b. Expectation Loops Dimasa Krisis

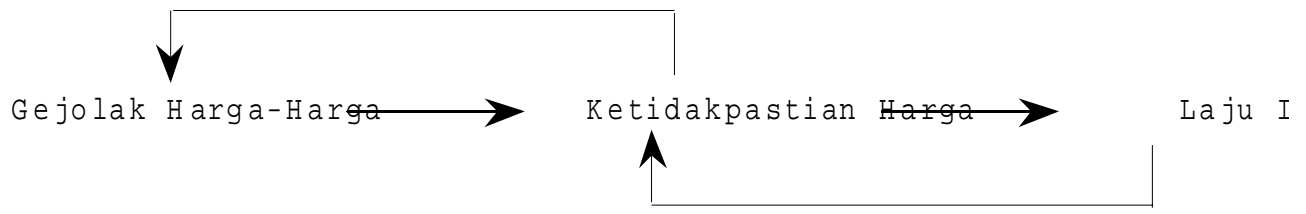

\section{B. Backward Looking Expectation}

Analisa mengenai dinamika ekspektasi inflasi backward didasarkan pada asumsi bahwa ekspektasi inflasi pelaku ekonomi secara umum bereaksi terhadap komponenkomponen berikut: (1) pengaruh laju inflasi historis terhadap laju inflasi bulan berjalan (inertia) ${ }^{12}$, (2) dinamika historis level kurs nilai tukar Rp/USD, dan (3) kredibilitas historis disinflationary policy pemerintah ${ }^{13}$.

\section{Inertia di Masa Krisis}

Observasi sekilas terhadap data inflasi IHK Indonesia dengan menggunakan dua periode yaitu periode diluar krisis moneter (06/1990 - 06/1997) dan periode yang memasukkan krisis moneter (06/1990 - 09/1998) menunjukkan bahwa kadar inertia dalam series inflasi IHK telah meningkat sepanjang krisis moneter Hal ini ditunjukkan oleh meningkatnya persistensi laju inflasi IHK pada periode observasi yang memasukkan krisis

12 Wignall, Adrian Blundell, Lowe P., dan Tarditi, A. Inflation, Indicators, and Monetary Policy, dalam Inflation, Disinflation, dan Monetary Policy, Proceedings of a Conference, RBA, 1992.

13 Studi yang sama dilakukan pula of Bank of Canada hanya kredibilitas pada penelitian BoC dimasukkan sebagai komponen endogen dalam model forward looking , lihat: Maclean, Dinah. Incorporating Credibility in Forward Looking Models: Some Examples with QPM. Bank of Canada. 
Tabel 6 . Aucorrelation dalam Series Inflasi IHK Periode 06/1990 - 06/1997 vs. 06/1990 - 09/1998

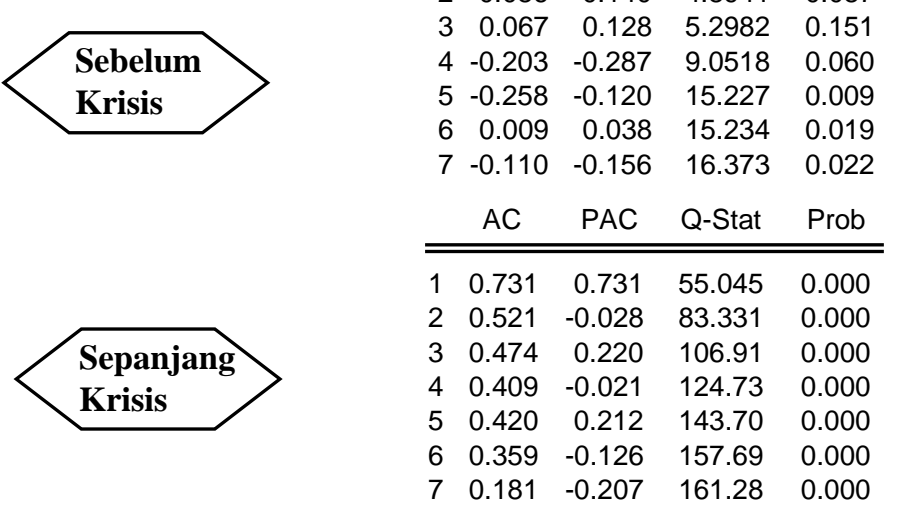

moneter. Tabel 6 menampilkan angka-angka autocorrelation ${ }^{14}$ dalam dua periode observasi. Tujuh kelompok angka teratas menunjukkan bahwa sebelum krisis moneter persistensi inflasi IHK sangatlah lemah, dimana inertia inflasi hanya disebabkan oleh laju inflasi satu bulan yang lalu. Dilain pihak, pada observasi yang memasukkan krisis moneter terlihat bahwa persistensi (inertia) inflasi dapat diterangkan oleh laju inflasi itu sendiri sampai tujuh bulan lag. Selanjutnya, tekanan inflasi satu bulan yang lalu pada observasi yang memasukkan periode krisis moneter menunjukkan pula bahwa inertia setelah adanya krisis meningkat dari $0.22 \mathrm{ke} 0.73$. Hal ini berarti 73\% dari inflasi dimasa krisis diterangkan oleh inflasi 1 bulan yang lalu, sedangkan dimasa sebelum krisis hanya 22\% inflasi bulan berlangsung diterangkan oleh inflasi bulan sebelumnya.

Observasi mengenai angka partial autocorrelation laju inflasi IHK sebelum dan sepanjang krisis moneter, memperlihatkan kuatnya inertia sampai tujuh bulan lags dimasa krisis dalam membentuk informasi dalam laju inflasi bulan berjalan, ceteris paribus. Hal ini ditunjukkan oleh tingginya Q-Statistics correlogram pada periode ini. Sebaliknya, dimasa sebelum krisis perbedaan yang mendasar terlihat pada angka Q-Statistics yang cenderung jauh lebih rendah. Selain itu, di masa sebelum krisis, partial autocorrelation pada lag 3 bulan tidak relevan dalam menerangkan laju inflasi bulan berjalan.

14 Autocorrelation di definisikan sebagai keterkaitan secara statistik antara suatu angka terhadap angka-angka sebelumnya, yang sekaligus menandakan bahwa persentase tertentu pada angka saat ini terjadi karena informasi-informasi yang melekat pada angka masa lalu terbawa ke masa kini (inertia). Lihat Enders, W. E. Applied Econometrics Time Series, Bab. 2. Stationary Time Series Models, Sub-bab 5 Autocorrelation Function, Willey \& Sons, New York, 1995. Lihat juga Sandy, R. Statistics for Business and Economics, McGraw Hill, New York, 1990, sub-bab 15.3 Autoregressive and Moving Average Models. 
Fenomena kuatnya inertia dimasa krisis kiranya memberi penjelasan adanya perubahan dinamika ekspektasi inflasi dalam perekonomian. Dimasa krisis terlihat bahwa masyarakat lebih sensitif terhadap perkembangan inflasi (inflation conscious) sehingga laju inflasi historis dapat secara signifikan menyumbang pada pembentukan ekspektasi inflasi masyarakat dimasa datang.

Gambaran umum mengenai inertia dan sumbangannya dalam proses pembentukan ekspektasi inflasi oleh pelaku ekonomi selanjutnya membawa analisa lebih jauh lagi pada proyeksi ekspektasi inflasi kedepan dengan model persamaan inertia. Dengan model persamaan ini ekspektasi inflasi pelaku ekonomi dibentuk oleh proses autoregressive moving average, dimana pelaku ekonomi melihat pergerakan laju inflasi pada bulan-bulan yang lalu dan melakukan koreksi terhadap kesalahan prediksi yang mereka lakukan. Oleh karena itu untuk memperoleh angka-angka pembentuk taksiran ekspektasi inflasi pelaku ekonomi, maka dicari suatu persamaan univariate ARIMA yang best-fit. Dari penelitian diperoleh bahwa laju inflasi IHK (CPI, I (1)) dengan proses $\alpha+\beta 1$ CPI(t-1) $+\beta 2$ CPI(t-2) $+\beta 3$ CPI (t-3) $+\varepsilon t+M A(1)$ adalah model yang cukup baik dalam menerangkan perilaku laju inflasi pada bulan berlangsung ${ }^{15}$. Dapat dilihat pada grafik 7 bahwa inertia laju inflasi IHK masih sangat kuat. Oleh karena itu, walaupun terjadi penurunan laju inflasi IHK secara bertutur-turut di triwulan III / 98, ekspektasi laju inflasi bulanan yang terbentuk dari proses inertia ini cenderung masih tetap kuat sampai akhir 1999, dengan rata-rata kisaran laju inflasi bulanan sebesar kurang lebih $4-4.5 \%$.

Grafik 7. Laju Inflasi IHK Aktual dan Inertia Sampai dengan Desember 1999

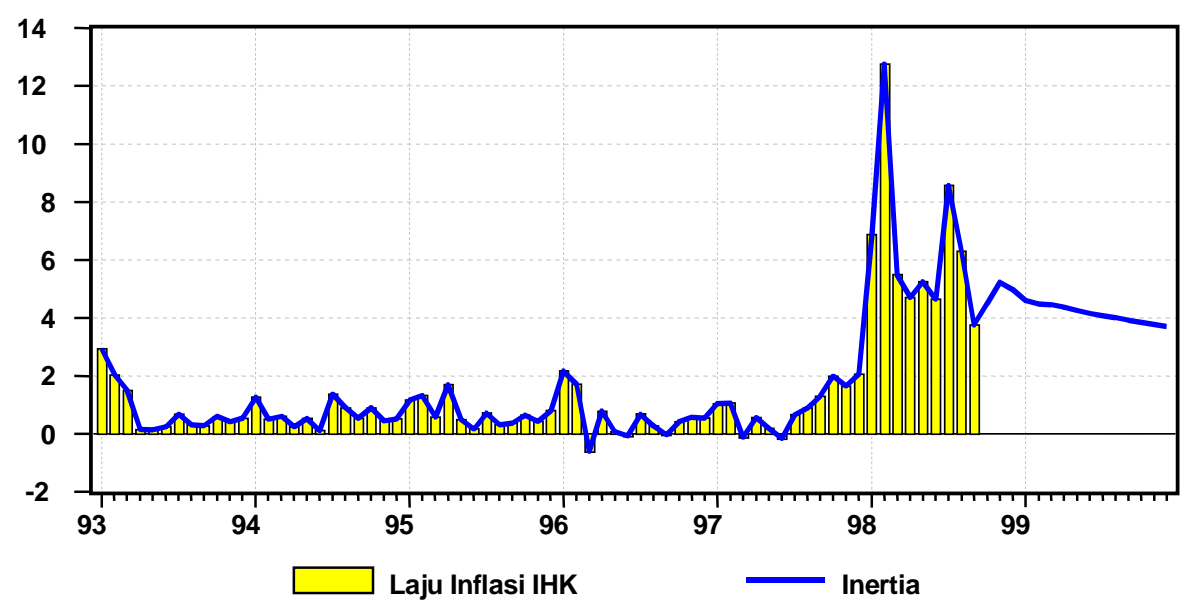

15 Hasil ekonometri dari persamaan ini dapat dilihat pada Annex-2 


\section{Ekspektasi Kurs Nilai Tukar Rp/USD Historis}

Komponen kedua dari ekspektasi inflasi backward looking adalah ekspektasi kurs nilai tukar yang didasarkan pada perilaku historis kurs nilai tukar Rupiah terhadap USD. Sejalan dengan semakin terbukanya perekonomian nasional, maka rentanitas laju inflasi terhadap gejolak ekstemal menjadi lebih lebih tinggi. Sebagaimana telah diketahui bersama, dengan dilepasnya band intervensi maka pergerakan kurs nilai tukar Rp/USD menjadi tidak terbatas dan sepenuhnya ditentukan oleh pasar. Perkembangan ini merupakan gejolak terbuka yang langsung berpengaruh pada harga-harga barang impor dan selanjutnya meningkatkan sensitifitas imported inflation. Fluktuasi imported inflation tersebut selanjutnya akan tercemin sebagai first-stage pass through apresiasi USD pada harga-harga barang tradeables.

Pada perkembangan berikutnya kenaikan harga karena first-stage pass-through akan memberi tekanan second - stage pass through yang tercemin dari pergerakan inflasi barangbarang nontradbables ( barang-barang yang diproduksi dan dikonsumsi secara domestik) Second - stage pass through tersebut berasal dari dua arah, yaitu (1) upward price adjustment yang dilakukan oleh para pengusaha karena naiknya harga input yang terkait dengan nilai tukar, dan (2) upward wage adjustment yang dilakukan oleh para pekerja di sektor informal yang tidak terikat oleh ketentuan upah minimum regional (UMR), untuk menyesuaikan dengan kenaikan biaya hidup.

Ekspektasi inflasi yang mempertimbangkan perilaku historis kurs nilai tukar Rp/ USD secara kuantitatif diukur sebagai proses distribated lags perubahan kurs Rp/USD bulanan dengan koreksi pelaku ekonomi terhadap kesalahan prediksi kursnya. Pembentukan ekspektasi kurs itu sendiri ditunjukkan oleh pelaku ekonomi yang terlibat dalam proses adaptive 1 bulan kebelakang dan leaming sepanjang 2 bulan kebelakang ${ }^{16}$. Sehingga, taksiran ekspektasi kurs Rp/USD secara backward looking adalah sama dengan proses ARMA $(1,0,2)$. Hasil yang diperoleh berdasarkan taksiran dengan proses ARMA $(1,0,2)$ tersebut adalah ekspektasi level kurs Rp/USD yang cenderung melemah pada bulanbulan kedepan. Sampai dengan akhir Semester II / 1999 kurs Rp/USD ditaksir mendekati Rp 7,000 / 1USD.

Secara teoritis, seiring dengan ekpektasi akan melemahnya nilai tukar Rp/USD, tekanan first dan second stage pass-through juga diekspektasikan masih akan kuat sehingga ekspektasi inflasi dengan menggunakan ekspektasi kurs backward looking cenderung akan meningkat. Dengan berasumsi bahwa pelaku ekonomi akan melihat net-effects dari level nilai tukar Rp/USD dalam membentuk ekspektasi inflasinya, maka hasil estimasi

16 Hasil estimasi ekonometri dapat dilihat di Annex - 3 
Grafik 8. Laju Inflasi IHK Aktual dan Ekspektasi Inflasi dengan Ekspektasi Depresiasi Rp/USD Backward Looking

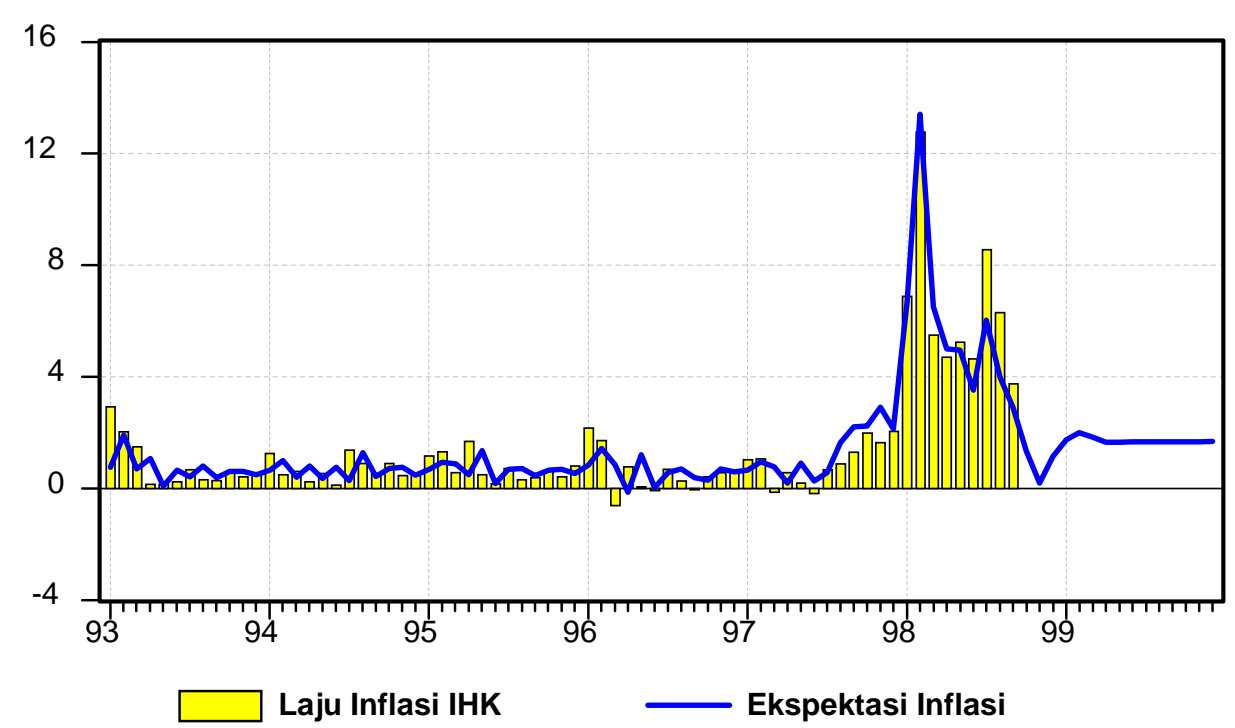

menunjukkan bahwa ekspektasi inflasi backward looking dibentuk oleh perubahan kurs nilai tukar sampai 4 bulan kebelakang ${ }^{17}$. Grafik 8 menampilkan ilustrasi ekspektasi inflasi sampai akhir 1999 berdasarkan taksiran ekspektasi kurs backward looking tadi. Ternyata, walaupun terdapat ekspektasi depresiasi Rp/USD laju inflasi IHK tetap diramalkan akan menurun oleh pelaku pasar. Hal ini kemungkinan besar disebabkan oleh masih adanya built-in expectation pelaku pasar bahwa walaupun secara backward looking akan terjadi depresiasi kurs Ro/USD tapi pemerintah akan berupaya menstabilisasi gejolaknya, sehingga depresiasi tersebut akan predictable seperti pada masa masih ada band intervensi.

\section{Kredibilitas Kebijakan Disinflasi Pemerintah}

Kemampuan pemerintah dalam mengendalikan inflasi mencerminkan kredibilitas pemerintah yang selanjutnya dijadikan ukuran ekspektasi inflasi oleh pelaku ekonomi. Ekspektasi inflasi berdasarkan kredibilitas pemerintah tersebut berasumsi bahwa: (1) pelaku ekonomi melihat sejarah keberhasilan kebijakan pengendalian inflasi oleh pemerintah dan memantau policy stance pemerintah dalam mengendalikan inflasi, dan (2) pelaku ekonomi merevisi ekspektasi selaras dengan observasi historisnya mengenai keberhasilan pemerintah dalam mengendalikan inflasi. Dengan asumsi demikian, maka dapat ditaksir suatu besaran yang mencerminkan kredibilitas disinflationary policy oleh pemerintah. Grafik 9 menyajikan

17 Hasil ekonometri lihat Annex-4 
Grafik 9. Laju Inflasi IHK, Perceived Target Inflasi, dan Kredibilitas Pemerintah

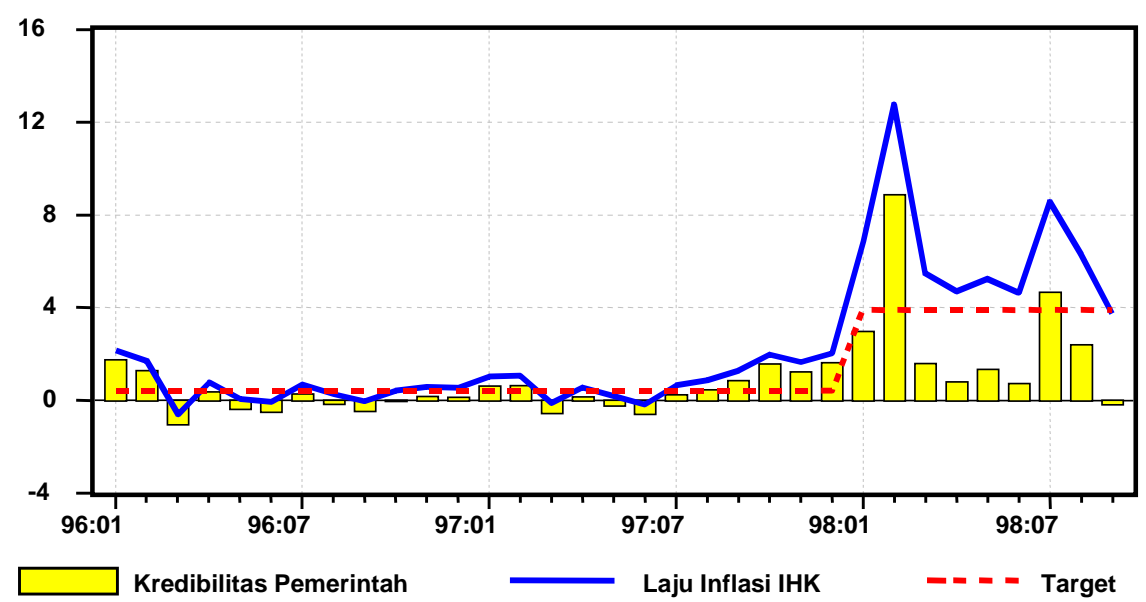

suatu ukuran kredibilitas disinflationary policy pemerintah, yang dihitung dengan mengurangi laju inflasi aktual dengan target inflasi pemerintah. Untuk periode 1990-1997 target inflasi adalah target Repelita sebesar rata-rata 5\% per tahun yang dibagi secara merata selama 12 bulan dan untuk tahun 1998 digunakan target APBN 1998/1999 sebesar 47\% per tahun yang didistribusikan sepanjang 12 bulan.

Dapat dilihat pada grafik bahwa sepanjang periode yang memasukkan krisis moneter, kredibilitas pemerintah tampaknya menurun seiring dengan meningkatnya deviasi laju inflasi aktual dari target. Hal ini tentama terlihat di triwulan IV/1997 ketika laju inflasi IHK berada diatas target. Sepanjang semester I / 1998 kredibilitas pemerintah menurun tajam di bulan Februari 1998 ketika panic buying melanda pasar barang-barang konsumsi. Setelah itu kredibilitas pemerintah membaik. Ketika harga Sembako melonjak tajam sejak Juni 1998, kredibilitas pemerintah sempat memburuk di bulan Agustus, untuk kemudian membaik lagi di bulan Sempember 1998. Memasuki Triwulan IV/1998 kredibilitas pemerintah tampaknya akan semakin membaik seiring dengan menurunnya deviasi laju inflasi dari target.

Berdasarkan ukuran kredibilitas diatas, taksiran terhadap efek kredibilitas pada ekspektasi inflasi backward looking dilakukan dengan berasumsi bahwa revisi ekpektasi pelaku ekonomi mengikuti observasi autoregressive terhadap kinerja pemerintah dalam mengendalikan inflasi. Selanjutnya, berdasarkan ekspektasi pelaku ekonomi mengenai kemampuan pemerintah mengatasi krisis harga, ditaksir ekspektasi inflasi pelaku ekonomi kedepan. Persamaan liniear menunjukkan bahwa ekspektasi inflasi terbentuk dari pengamatan historis pelaku ekonomi terhadap keberhasilan kebijakan disinflasi pemerintah sampai empat 
bulan kebelakang dan revisi kesalahan prediksi pelaku ekonomi. Dari grafik dibawah ini tampak bahwa ekspektasi inflasi pelaku ekonomi sepanjang triwulan IV/1998- I/1999 cenderung membaik yang menunjukkan bahwa pelaku ekonomi cenderung percaya bahwa pemerintah akan melakukan all at efforts untuk menurunkan laju inflasi ${ }^{18}$

Grafik 10. Laju Inflasi IHK Aktual dan Ekspektasi Inflasi Dimana Pelaku Ekonomi Melihat Disinflationary Policy Pemerintah

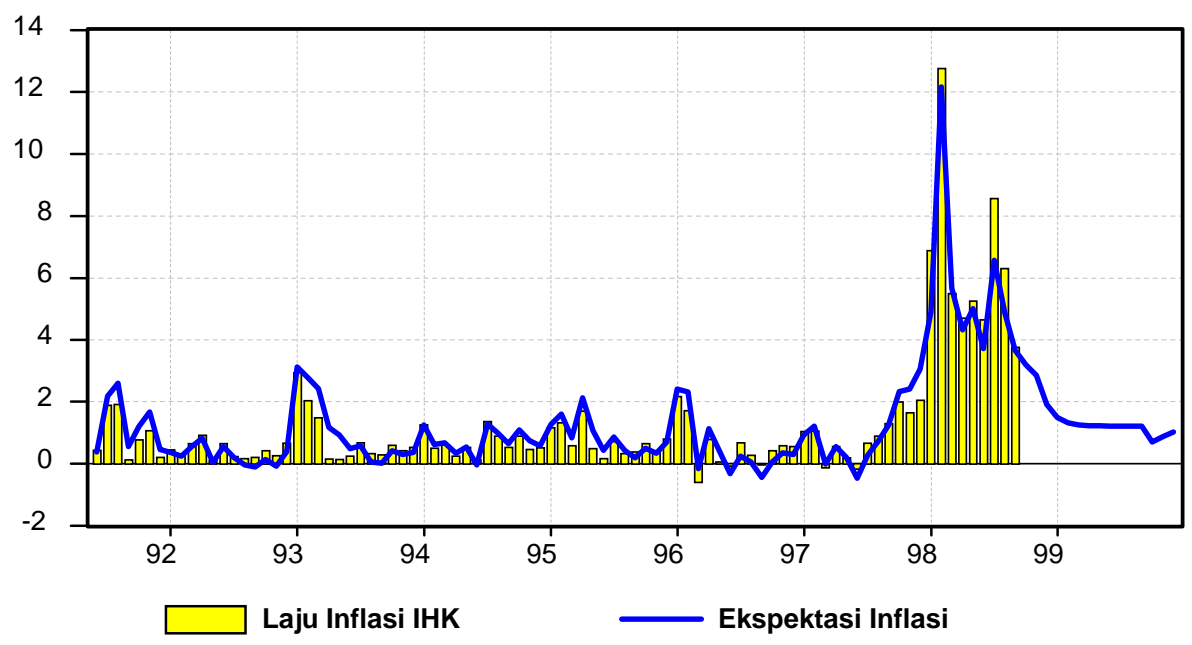

\section{Forward Looking Expectation}

Dengan berasumsi bahwa ekspektasi inflasi forward looking dibentuk oleh para pelaku pasar di pasar keuangan domestik dan valuta asing, maka indikator yang digunakan sebagai proksimasi ekspektasi inflasi adalah yield spread dipasar keuangan dan forward rate Rp/USD di pasar valuta asing. Perkembangan yield spread di pasar keuangan menunjukkan ekspektasi pelaku pasar terhadap discount nilai asset karena ekspektasi inflasi. Sedangkan, perkembangan formard rate di pasar valuta asing menunjukkan selisih suku bunga dalam dan luar negeri serta menunjukkan adanya ekspektasi level nilai tukar dimasa yang akan datang. Dengan semakin meningkatnya peranan nilai tukar dalam perekonomian nasional, maka pelaku ekonomi cenderung mengkaitkan pergerakan inflasi dengan ekspektasi perkembangan nilai tukar.

Untuk mentaksir besarnya koefisien pembentuk besamya ekspektasi inflasi forward looking maka disusun dua persamaan linier yang menyatakan bahwa laju inflasi IHK aktual adalah fungsi cari forward rate Rp/USD 12 bulan yang berlaku dipasar forward saat ini dan fungsi dari yield spread

18 Untuk hasil ekonometri lihat Annex-5 
di pasar keuangan. Selanjutnya berdasarkan kœefisien yang diperoleh dilakukan replikasi sampai September 1999 dengan menggunakan yield spread dan forward rate sejak Oktober 1997 sampai September $1998^{19}$.

Pada grafik dibawah dapat dilihat ekspektasi inflasi yang terjadi di pasar keuangan (grafik 11a) dan pasar valas (grafik 11b), terlihat bahwa pada masa sebelum krisis moneter, ekspektasi inflasi tersebut cendenung dapat mentaksir dengan baik inflasi yang akan terjadi. Akan tetapi sepanjang krisis moneter, ekspektasi inflasi pada masing-masing pasar cendenung ikut bergejolak seiring dengan ketidakpastian harga-harga di pasar komoditas.

Grafik 11a. Laju Inflasi IHK dan Ekspektasi Inflasi di Pasar Keuangan

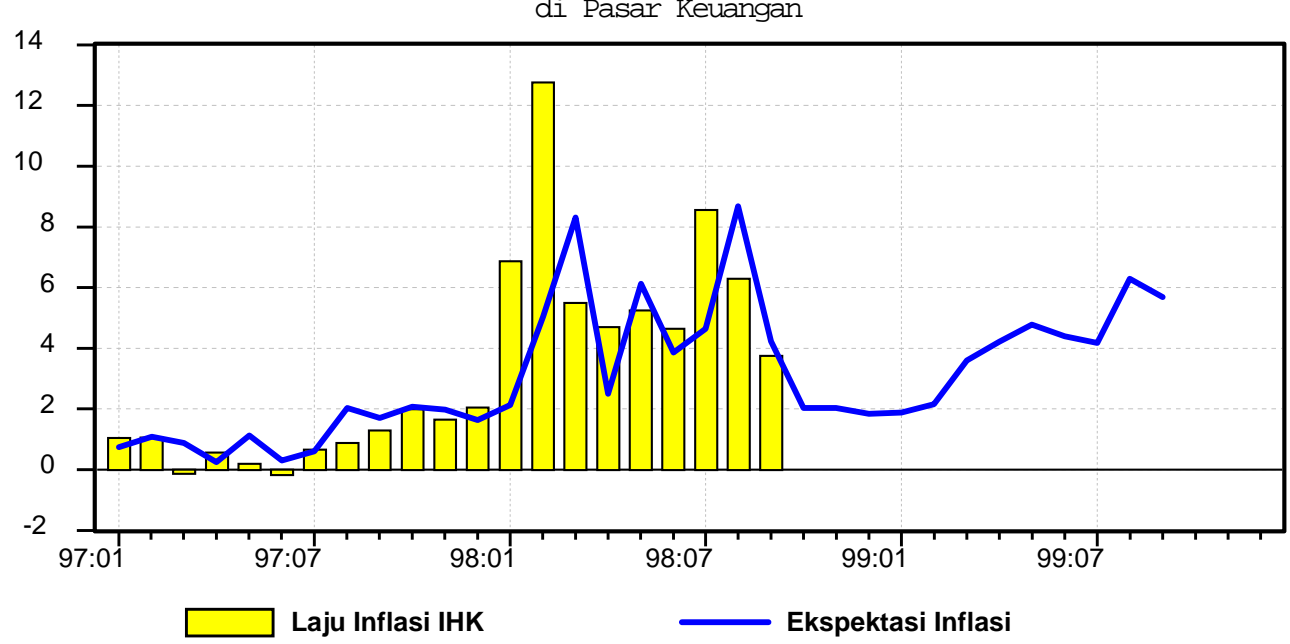

Grafik 11b. Laju Inflasi IHK dan Ekspektasi Inflasi di Pasar Valas

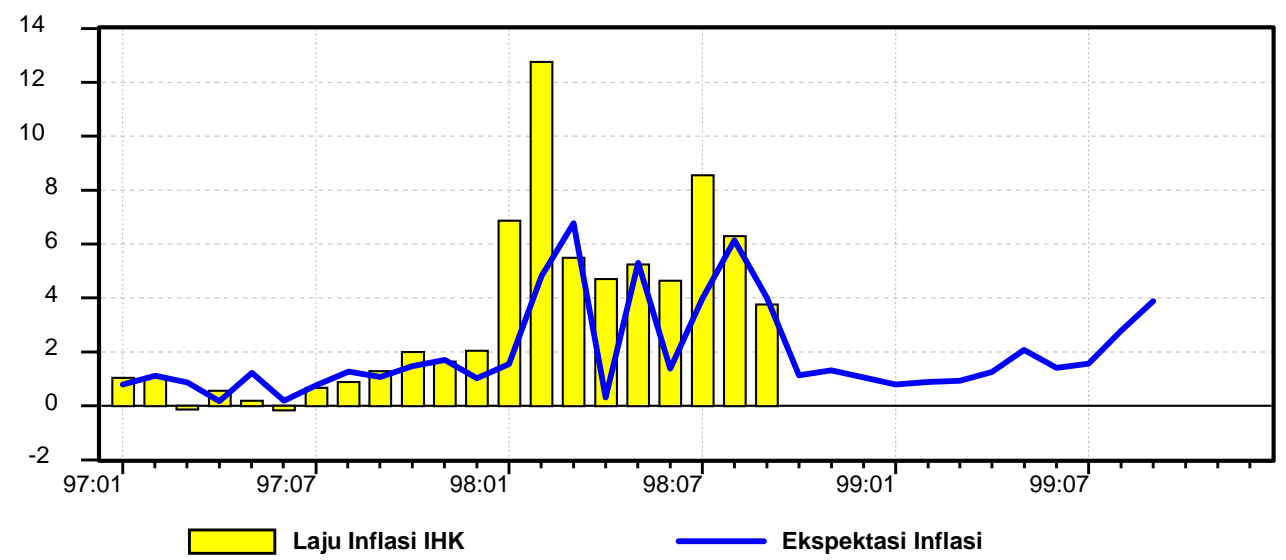

19 Untuk hasil ekonometri lihat Annex-6 
Selanjutnya, khusus untuk angka estimasi forward rate tampaknya masih terkandung unsur linear correlation dan multicolinierity dalam hasil ekonometri. Untuk itu dilakukan Pengujian Granger Causality guna melihat kenyataan empiris hubungan kausalitas antara laju inflasi dan forward rate di pasar valas. Hasil pengujian menunjukkan bahwa dimasa krisis hubungan kausalitas antara laju inflasi IHK dan forward rate dipasar valas berlangsung dua arah sampai 12 bulan lag. Walaupun begitu, hubungan kausalitas dari laju inflasi ke forward rate cenderung jauh lebih kuat. Pada masa sebelum krisis moneter hubungan kausalitas berlangsung dua arah dengan lag yang berbeda, yaitu pada lag 3, 4, dan 5 bulan cari forward rate ke laju inflasi dan kausalitas sebaliknya pada lag 10 dan 11 bulan. Hal ini berarti pula bahwa setiap upaya disinflationary yang berhasil akan mengalami proses feet through ke pasar valas yang menopang stabilisasi nilai tukar Rp/USD ${ }^{20}$.

\section{Ekspektasi Inflasi}

Dengan hasil-hasil ekspektasi inflasi yang diperoleh melalui forward dan backward looking dapat diperoleh suatu ukuran rata-rata tidak terbobot (unweighted average) dari kelima komponen pembentuk ekspektasi inflasi. Selanjutnya dilakukan proses pembobotan ulang dengan metode neural network untuk mengakomodasi bounded rationality para pelaku ekonomi dimasa krisis yang penuh ketidakpastian²1.Setting neuron logsismoid dilakukan sebagai proses pengaruh kelima komponen pada rata-rata tidak terbobot ekspektasi inflation (Neuron Net CPI e = Neuron (Inertia, Kurs Rp/USD, Kredibilitas Pemerintah, Yield Spread, Forward Rate Rp/ USD) Desain transformasi logsismoid ini mengikuti pola dimana setiap neuron akan masuk kedalam hidden neuron dimana terjadi backpropagation leaming untuk menangkap ephoria pelaku pasar. Hasil yang diperoleh adalah bobot dari masing-masing komponen dalam menyumbang pada ketidakpastian harga-harga, sebagaimana yang ditunjukkan di tabel dan grafik berikut:

Tabel 7. Bobot Setelah Melalui Proses Neural Network

Bobot : Ekspektasi Inflasi Karena:

Proses Backward Looking

0.26180 Kredibilitas Kebijakan Disinflasi

0.21305 Backward Exchange Rate Expectation

0.20608 Inertia

Proses Forward Looking:

0.19691 Yield Spread

0.12216 Forward Rate

20 Hasil ekonometri dapat dilihat di Annex-7

21 Metodologi neural network dapat dilihat di Annex-8 
Dapat dilihat pada tabel diatas, kredibilitas pemerintah memegang peranan penting dalam menentukan pembentukan ekspektasi inflasi masyarakat, disusul kemudian oleh ekspektasi kurs Rp/USD secara historis dan inertia inflasi IHK. Kesemua komponen ini adalah komponen ekspektasi inflasi backward looking.Forward rate Rp/USD dan yield spread, yang merupakan komponen ekspektasi forward looking ternyata secara total hanya berperan sebesar 32\% dalam pembentukan ekpektasi inflasi. Sehingga ekspektasi inflasi backward looking menyumbang 68\% dalam proses pembentukan ekspektasi inflasi.

Pada grafik 12 dapat dilihat pergerakan dari simulasi ekspektasi inflasi yang diperoleh dengan membobot ulang setiap komponen pembentuknya. Ekspektasi Inflasi cenderung mendekati laju inflasi aktual sebagaimana diceminkan oleh besarnya adjusted r-squared sebesar 0.99, coefficient correlation $r$ sebesar 0.99, dan rendahnya mean absolut error yaitu 0.087 (tabel 7).

Tabel 8. Hasil - Hasil Proses Neural Network

$\begin{array}{lrlr}\text { R squared: } & 0.9936 & \text { r squared: } & 0.9940 \\ \text { Mean squared error: } & 0.014 & \text { Mean absolute error: } & 0.087 \\ \text { Min. absolute error: } & 0.001 & \text { Max. absolute error: } & 0.426 \\ \text { Correlation coefficient r: } & 0.9970 & & \end{array}$

Grafik 12. Laju Inflasi IHK Aktual dan Ekspektasi Inflasi

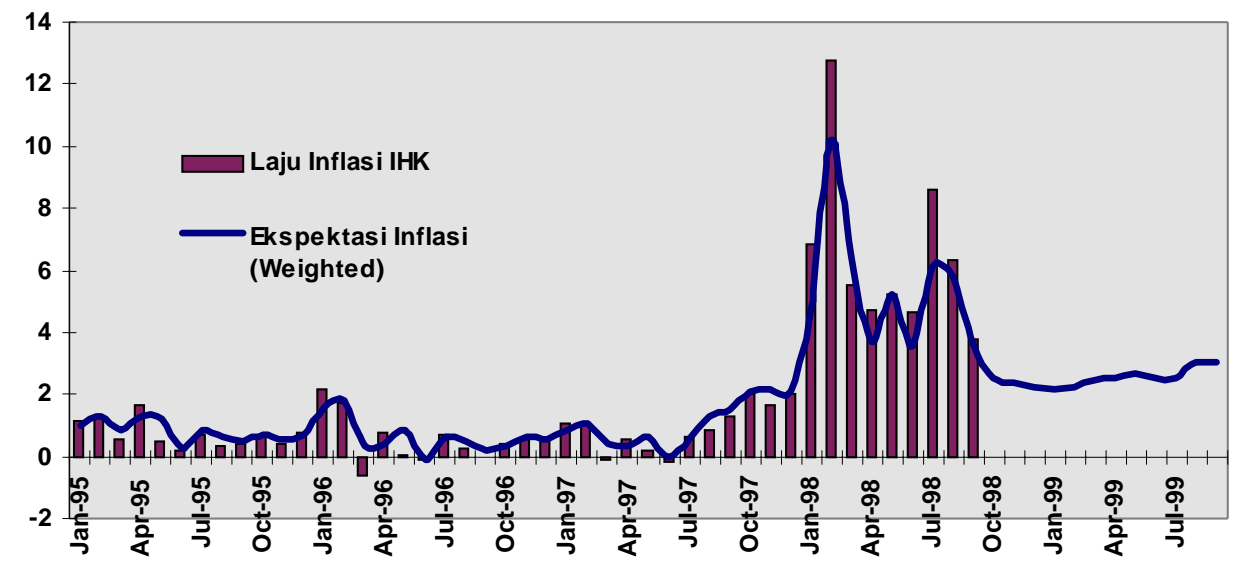

Hasil neural network ini menunjukkan bahwa komponen-komponen pembentuk ekspektasi backward dan forward looking diatas dapat mewakili prediksi arah pembentukan ekspektasi inflasi di masyarakat. Ditinjau dari masing-masing komponen, kredibilitas pemerintah dalam upaya untuk mencapai target inflasi cenderung menjadi benchmark bagi pelaku ekonomi dalam membentuk ekspektasi inflasi kedepan. Menurunnya kredibilitas pemerintah cenderung meningkatkan ekspektasi inflasi sebagaimana yang terilustrasi dalam periode Juli - Desember 1997 dan Januari serta Agustus 1998. 
Kesimpulan

Berdasarkan hasil penelitian diatas, dapat disimpulkan bahwa secara umum:

- Perilaku pelaku ekonomi dalam pembentukan ekspektasi inflasi mengalami perubahan dari masa sebelum krisis dan sepanjang krisis. Dalam periode sebelum krisis, proses pembentukan ekspektasi tidak terdapat interaksi timbal balik antara gejolak harga, ketidakpastian harga, dan laju inflasi. Sementara itu, dalam periode sepanjang krisis terdapat interaksi timbal balik (loop ekspektasi) antara gejolak harga, ketidakpastian, dan laju inflasi yang bersifat self-reinforcing. Ketidakpastian harga merupakan faktor terpenting dalam proses loop ekspektasi dimasa krisis, yang merupakan faktor pemicu pembentukan ekspektasi inflasi.

- Ekspektasi inflasi juga dapat dibentuk oleh proses backward dan forward looking. Komponen pembentuk ekspektasi inflasi backward looking adalah : kredibilitas pemerintah, inertia (inflasi secara historis), dan ekspektasi kurs Rp/USD. Sedangkan komponen pembentuk ekspektasi inflasi forward looking adalah yield spread dan forward rate RP/ USD. $68 \%$ pembentukan ekspektasi inflasi dimasa krisis mengikuti pola backward looking, dimana pelaku ekonomi mempelajari dan merevisi ekspektasinya berdasarkan pengalaman di masa lalu. Sehingga, inflasi yang tinggi dimasa lalu cenderung membentuk ekspektasi inflasi yang masih tetap tinggi dimasa mendatang, demikian pula sebaliknya.

* Kredibilitas pemerintah merupakan komponen utama dalam menentukan ekspektasi inflasi masyarakat. Semakin tinggi deviasi keberhasilan disinflationary policy pemerintah dari inflasi yang ditargetkan, maka semakin tinggi ekspektasi inflasi masyarakat. Menurunnya kredibilitas pemerintah ditunjukkan oleh temuan bahwa dituntut adanya lima bulan konsistensi keberhasilan pemerintah dalam mengendalikan inflasi dimasa krisis agar ekspektasi inflasi bisa menurun .

- Nilai tukar Rp/USD secara historis merupakan acuan masyarakat dalam mengantisipasi inflasi dimasa mendatang, walaupun demikian terdapat indikasi kuat bahwa ekspektasi depresiasi nilai tukar Rp/USD di pasar forward dibentuk dengan mempertimbangkan ekspektasi inflasi historis.

- Dimasa krisis laju inflasi secara historis kuat mempengaruhi pembentukan ekspektasi inflasi pelaku ekonomi. Dengan demikian inflasi yang masih tetap tinggi akan cenderung membentuk ekspektasi inflasi yang masih tinggi.

- Jika pengendalian inflasi dimasa krisis dapat menurunkan harga secara berkelanjutan selama lima bulan berturut-turut, maka yang akan terjadi adalah downward spiral inflasi yang menurunkan tekanan laju inflasi dan selanjutnya dapat menopang perbaikan kurs nilai tukar Rp/USD dipasar valas. 
Implikasi Kebijakan

Struktural

Perkembangan pengendalian inflasi sampai dengan akhir triwulan III /1998 tampaknya menunjukkan arah yang membaik. Keberhasilan pengendalian inflasi tersebut telah meningkatkan kredibilitas pengendalian inflasi oleh pemerintah, sehingga ekspektasi inflasi backward looking dari sisi kredibilitas akan cenderung menurun. Jika pemerintah berhasil menurunkan laju inflasi lebih lanjut di bulan Oktober 1998 melalui kebijakan struktural yang lebih komprehensif seperti anatara lain mempenbaiki sistem distribusi bahan pokok dalam jangka pendek dan stabilitas keamanan, maka kepastian harga akan lebih mudah tercapai. Oleh karena itu agenda pemerintah dalam jangka pendek (3-4 bulan kedepan) adalah mengutamakan perbaikan sisi distribusi bahan kebutuhan pokok. Selanjutnya di bulan November dan Desember 1998 seiring dengan datangnya bulan Ramadhan pemerintah perlu mempertahankan harga sembako agar tidak kembali bergejolak dengan meningkatkan supply produk-produk utama dalam kelompok sembako (beras, gula, minyak goreng, daging, telur, dan susu). Jika target jangka pendek diatas tercapai, maka dapat diantisipasi bahwa akan ada downward spiral inflasi diawal 1999 melalui self-reinforcing expectation loop karena penurunan laju inflasi dan meningkatnya kredibilitas pemerintah dimata masyarakat. Dalam jangka panjang pemerintah perlu terus mengupayakan pengembangan sektor pertanian, termasuk agribisnis baik yang berorientasi ekspor maupun untuk pasokan dalam negeri.

Moneter

Kendati dari hasil simulasi ekspektasi inflasi dimasa mendatang telah menunjukkan penurunan akan tetapi masih tetap berada pada tingkat yang tinggi. Oleh karena itu, otoritas moneter harus terus memantau inflasi khususnya yang bersumber dari fenomona moneter dalam perekonomian. Selanjutnya, mengingat pembentukan inflasi IHK dalam jangka pendek tidak semata-mata merupakan fenomena moneter, namun juga dibentuk oleh fenomena di sisi supply, maka otoritas moneter perlu memilah-milah sumber-sumber penyebab inflasi. Otoritas moneter dapat menggunakan simulasi ini sebagai salah satu altematif benchmark dalam menetapkan target inflasi dan kebijakan moneter dimasa mendatang dengan mempertimbangkan lag kebijakan moneter ke inflasi. Disamping itu stabilitas nilai tukar juga harus tetap mendapat perhatian dalam upaya menunjang penurunan ekspektasi inflasi masyarakat.

Secara umum, Bank Indonesia perlu mempertimbangkan koordinasi penurunan ekspektasi inflasi backward looking melalui masukan-masukan untuk perbaikan struktural di sisi penawaran kepada pemerintah c.q departemen terkait. Penurunan ekspektasi inflasi 
tersebut selanjutnya akan ter-transmisi dalam forward rate Rp/USD dipasar valas yang kemudian dengan sendirinya akan menurunkan ekspektasi inflasi lebih lanjut. Jika terdapat indikasi bahwa feed through tersebut dapat mempertahankan nilai tukar Rp/USD pada level yang sustainable, maka untuk kedepannya Bank Indonesia perlu mengumumkan kepada masyarakat hal -hal berikut untuk preemptive disinflationary policy dalam mengendalikan inflasi: (1) jenis-jenis tekanan inflasi yang berada diluar jangkauan Bank Indonesia (escape clause) dalam pengendalian inflasi moneter yang perlu segera diambil alih oleh pemerintah c.q. departemen terkait melalui supply side policy, (2) menetapkan target band inflasi akibat fenomena moneter serta indikator pemantaunya (leading indicator), dan (3) jenis-jenis kebijakan moneter yang akan diambil oleh Bank Indonesia bila tekanan inflasi dari sisi moneter mulai mengarah keluar diatas band.

\section{Daftar Pustaka}

King, Marvyn, Do Inflation Targets Work?, Address to the Center for Economic Policy Research.

Griliches, Zvi, Distribution Lags : A Survey, Econometrica, Vo. 35, No. 1, January 1967

Bomfim, A. dan Brayton, F., Long Run Inflation Expectation and Mbnetary Policy, BIS.

Dillen, H. dan Hopkins, E., Forward Interest Rates and Inflation Expectations: The Role of Regime Shift Premia and Monetary Policy, BIS.

H unt, B., Conway, P., dan Scott, A., Exchange Rate Effects and Inflation Targeting in A Small Open economy, a Stochastic Analysis Using FPS, BIS.

Ireland, Peter N., Long Tem Interest Rates and Inflation: A Fisherian Approach, FRB of Richmond.

Kandel, S. , Ofer, A. dan Sarig, O., Real Interest Rates and Inflation: An Ex Ante Empirical Analysis, The Journal of Finance, Vol 11, No. 1, March 1986.

De Brouwer, G. dan Ericsson, N., Mbdelling Inflation in Australia, RBA.

McKibbin, W., Which Monetary Policy Regime for Australia, RBA.

Cecchetti, S., Distingushing Theories of The Monetary Transmission Mechanism, FRB of St. Louis.

Cecohetti, S., Inflation Indicators and Inflation Policy, Ohio State Univ.

Dwyer, J. dan Lam, R., Explaining Import Price Inflation: A Recent History of Second Stage Pass Through, RBA. 
Gruen, D. dan Dwyer, J., Are Terms of Trade Rises Inflationary?, RBA.

Hakim, L. dan Solikin., Mbdel Inflasi dengan Pendekatan Neural Network, Kertas Keja Staff, BI.

Lin, W., Impulse Response Function for Conditional Volatility in GARCH Mbdels, Joumal of Business and Economic Statistics, January 1997.

O'Connor , M. Hill, T., Neural Network Mbdels for Time Series Forecast, Institute for Operation Research and Management Sciences.

Romalis, J., Gruen, D. dan Chandra, N., The Lags of Mbnetary Policy, RBA.

Santoso, W., Karakteristik Inflasi di Indonesia, UREM, BI.

Haslag, J., Monetary Aggregates and The Rate of Inflation, FRB of Dallas.

Simatupang, P., Diagnosa Penyebab Inflasi Dari Sisi Sektor Riil: Tinjauan Eksploratif, IPB.

Annex

I. Mengukur Taksiran Laju Inflasi Alternatif dan Indicator of Policy Severity

\section{Inflasi Karena Kurs dan Uang Beredar}

Untuk mengukur taksiran laju inflasi alternatif digunakan metode regresi linier sederhana dengan persamaan-persamaan berikut:

(1) $\mathrm{CPI}=\mathrm{FX}(-1)+\mathrm{FX}(-2)+\mathrm{FX}(-3)+\mathrm{FX}(-4)+\mathrm{MA}(1)$, untuk ukuran laju inflasi yang disebabkan oleh perubahan bulanan kurs nilai tukar Rp/USD, dimana CPI adalah laju inflasi IHK bulanan , FX adalah perubahan kurs Rp/USD bulanan, (L) adalah lag qperator, dan MA(1) adalah satu bulan koreksi terhadap kesalahan prediksi.

(A) $\mathrm{CPI}=$ Base $(-1)+$ Base $(-2)+$ Base $(-3)+$ Base $(-4)+M A(1)$, untuk ukuran laju inflasi yang disebabkan oleh pertumbuhan bulanan base money, dimana CPI adalah laju inflasi IHK bulanan, Base adalah pertumbuhan bulanan base money , (L) adalah lag qperator, dan MA(1) adalah satu bulan koreksi terhadap kesalahan prediksi.

Berdasarkan kedua persamaan diatas diperoleh hasil ekonometri sebagai berikut: 
Persamaan (1)

Dependent Variable: CP

Sample(adjusted): 1990:11 1998:09

Included observations: 95 after adjusting endpoints

Backcast 1

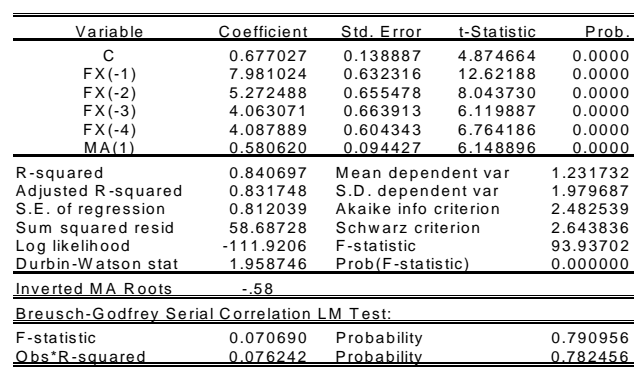

\section{Persamaan (2)}

Dependent Variable: CPI

Method: Least Squares

Sample(adjusted): 1990:10 1998:09

Included observations: 96 after adjusting endpoints Convergence achieved a

\begin{tabular}{|c|c|c|c|c|}
\hline Variable & Coefficient & Std. Error & $\mathrm{t}$-Statistic & Prob \\
\hline & 0.253030 & 0.315018 & 0.803226 & 0.42 \\
\hline BASE & & & & 00 \\
\hline BASE & & 98 & $4.2 C$ & .0001 \\
\hline BASE $(-3)$ & & 99 & & \\
\hline BASE $(-4)$ & & & 3.164416 & \\
\hline$M A(1)$ & 0.774237 & 0.067076 & 11.54264 & 0.0000 \\
\hline R-squared & 0.595983 & \multirow{6}{*}{\multicolumn{2}{|c|}{$\begin{array}{l}\text { Mean dependent var } \\
\text { S.D. dependent var } \\
\text { Akaike info criterion } \\
\text { Schwarz criterion } \\
\text { F-statistic } \\
\text { Prob(F-statistic) }\end{array}$}} & 1.229649 \\
\hline Adjusted R-squared & 0.573538 & & & 1.969346 \\
\hline S.E. of regression & 1.286063 & & & 3.401510 \\
\hline Sum squared resid & 148.8562 & & & 3.561781 \\
\hline Log likelihood & -157.2725 & & & 26.55262 \\
\hline Durbin-Watson stat & 1.865567 & & & 0.000000 \\
\hline \multicolumn{5}{|c|}{-.77} \\
\hline \multicolumn{5}{|c|}{ Breusch-Godfrey Serial Correlation LM Test: } \\
\hline $\begin{array}{l}\text { F-statistic } \\
\text { Obs } R \text {-squared }\end{array}$ & $\begin{array}{l}0.644135 \\
0.689801\end{array}$ & $\begin{array}{l}\text { Probability } \\
\text { Probability }\end{array}$ & & $\begin{array}{l}0.424355 \\
0.406232\end{array}$ \\
\hline
\end{tabular}

Dengan diperolehnya parameter-parameter persamaan diatas selanjutnya ditaksir ukuran laju inflasi yang disebabkan oleh perubahan bulanan kurs Rp/USD dan pertumbuhan bulanan base money. Untuk itu dilakukan in-sample (static) forecast pada kedua persamaan. Hasil yang diperoleh adalah sebagai berikut:

Laju Inflasi Karena Perubahan Bulanan Kurs Rp/USD (CPIKURS)
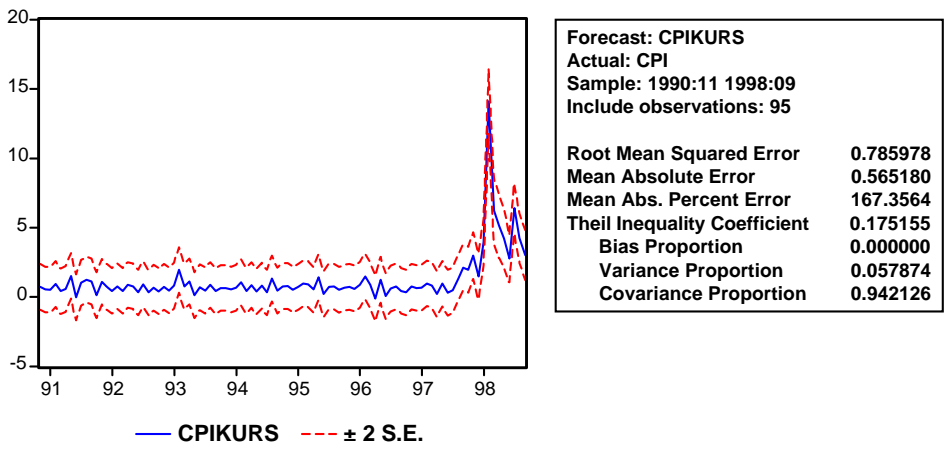

Laju Inflasi Karena Pertumbuhan Bulanan Uang Beredar (CPIBASE)



Forecast: CPIBASE

Actual: $\mathrm{CPI}$

Sample: 1990:10 1998:09

Include observations: 96

Root Mean Squared Error 1.245225 $\begin{array}{ll}\text { Mean Absolute Error } & 0.851097 \\ \text { Mean Abs. Percent Error } & 241.2239\end{array}$ Theil Inequality Coefficient 0.297043 Bias Proportion 0.000000 Variance Proportion $\quad 0.186663$ Covariance Proportion 0.813337

— CPIBASE --- \pm 2 S.E. 


\section{Laju Inflasi Karena Permintaan Agregat (Underlying Inflation)}

Laju inflasi karena pemintaan agregat (underlying inflation) di ukur dengan berasumsi bahwa atliers dalan histogram bulanan keranjang inflasi IHK adalah noise yang bersifat temporer dan tidak mencerminkan tekanan riil dari sisi permintaan ageregat. Oleh karena itu untuk mengukur laju underlying inflation, dilakukan pemangkasan terhadap keranjang inflasi IHK secara bulanan. Hasil uji statistik tentang ukuran underlying inflation yang paling efisien (robust) menunjukkan bahwa pemangkasan sebesar 17.5\% pada kedua tails histogram bulanan keranjang inflasi IHK adalah nilai kritikal yang terbaik ${ }^{22}$.

Berdasarkan metode pemangkasan diperoleh suatu taksiran underlying inflation sebagaimana yang ditunjukkan oleh grafik berikut. Selisih antara laju inflasi aktual dengan underlying inflation adalah temporary disturbances (noise) dalam keranjang inflasi IHK.

Noise, Underlying Inflation, dan Laju Inflasi IHK Aktual

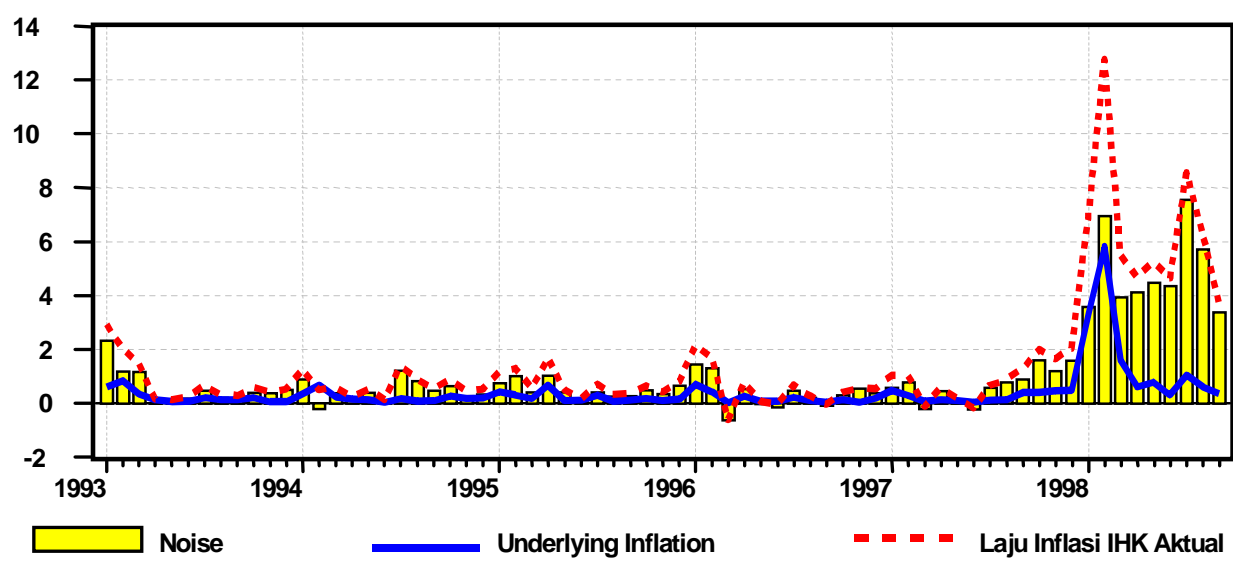

3. Indicator of Policy Severity

Indicator of Policy Severity (IPS) adalah indikator yang menunjukkan stance kebijakan moneter sepanjang waktu. Grafik indikator yang meningkat menunjukkan stance kebijakan moneter yang ketat, sedangkan grafik yang menurun menunjukkan stance yang loose. Untuk menyusun indikator ini digunakan rumus berikut IPS = ( (C - Mean C) / Stdev. C) - (D- Mean D) / Stckv. D), dimana IPS adalah indicator of policy severity, C adalah tingkat suku bunga riil jangka pendek, dan D adalah spread antara suku bunga jangka panjang dan pendek nominal.

IPS Indonesia disusun dengan menggunakan policy andhor Bank Indonesia, yaitu SBI 30 hari sebagai proksi dari C, dan spread antara suku bunga deposito 1 dan 24 bulan sebagai proksi dari D. Masing komponen pembentuk IPS ini diilustrasikan pada grafik berikut.

22 Lihat hasil penelitian mengenai “Indikator Harga yang Relevan Dengan Kebijakan Moneter", Program Kerja UREM 1997-1998. 
Komponen-Komponen Pembentuk IPS


Dengan menggunakan komponen-komponen diatas dan rumus IPS, telah disusun IPS Indonesia sebagaimana yang diilustrasikan oleh grafik berikut:

Indicator of Policy Severity

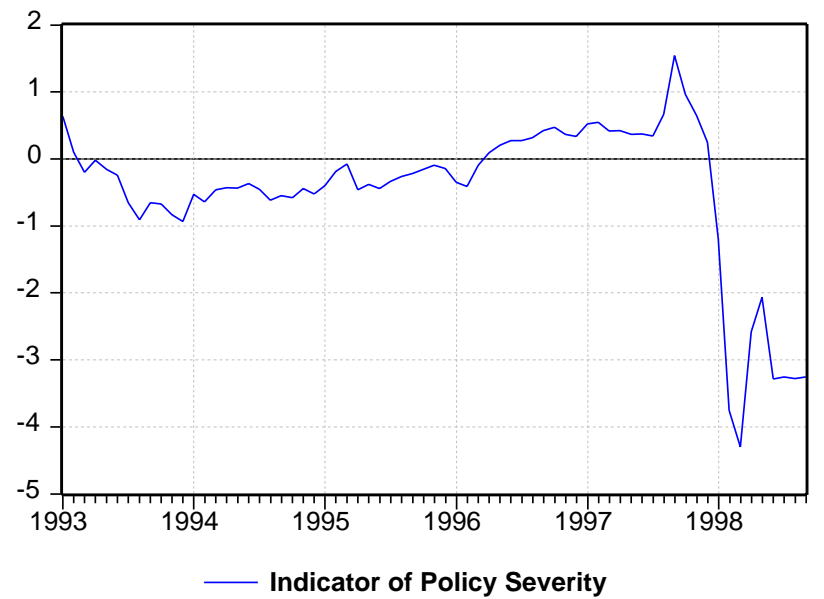

Dapat dilihat pada grafik diatas pada periode 1990 - 1995 kebijakan moneter di Indonesia secara riil berada pada kondisi loose, kemudian memasuki 1996 sampai pertengahan 1997 stance kebijakan moneter adalah tight. Diera krisis, kebijakan moneter secara riil adalah sangat loose. 
II. Mengukur Ekspektasi Dengan Inertia

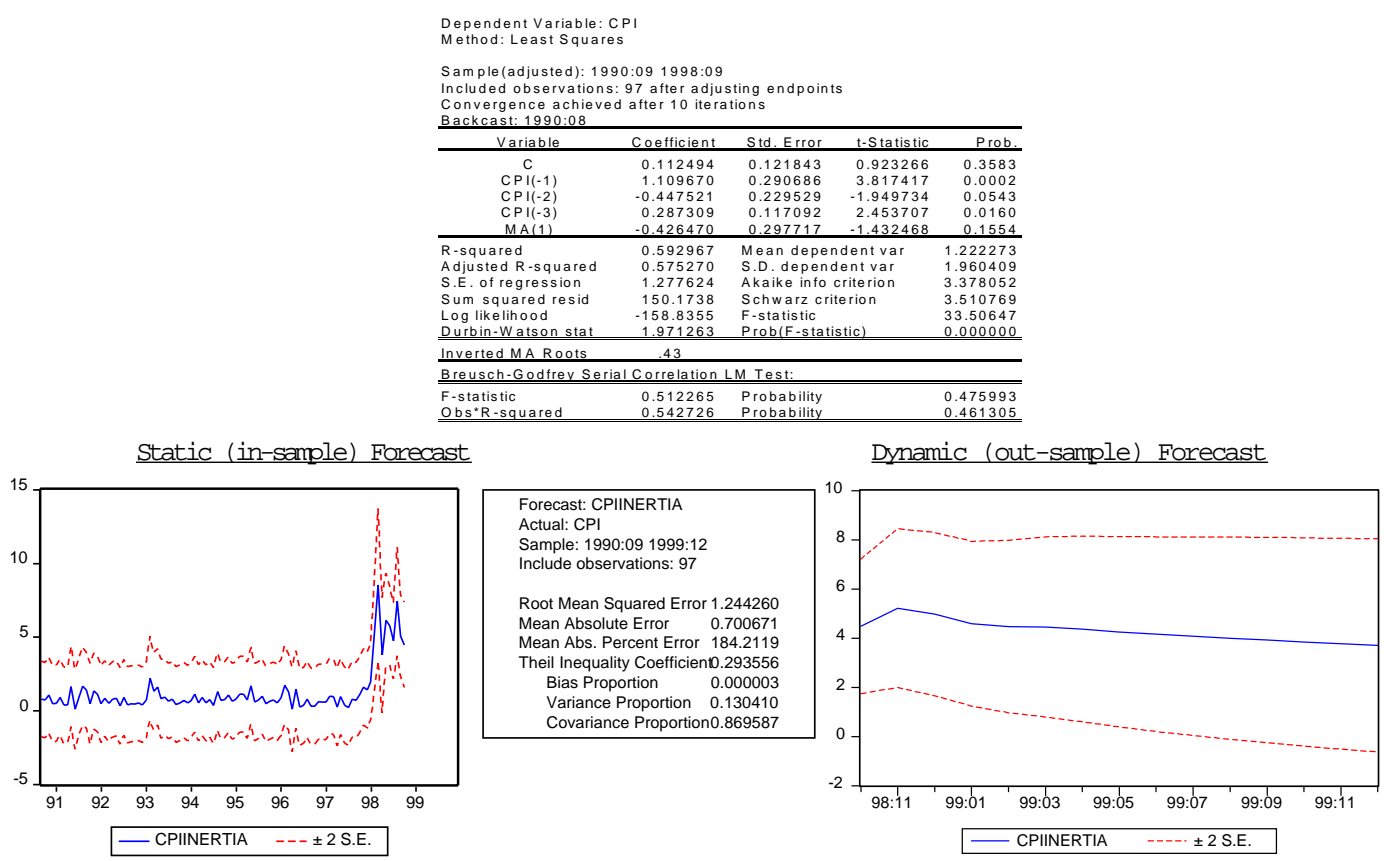

\section{Mengukur Ekspektasi Kurs Secara Backward Looking}

Dependent Variable: KURS
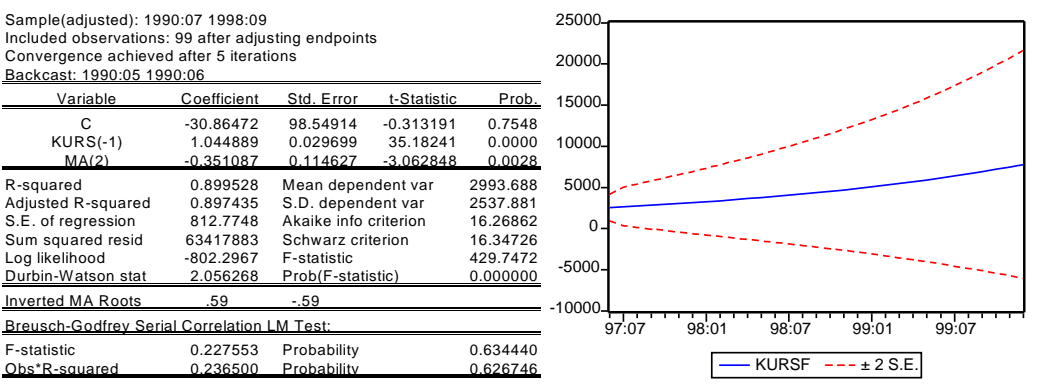

\begin{tabular}{|c|c|}
\hline \multicolumn{2}{|l|}{$\begin{array}{l}\text { Forecast: KURSF } \\
\text { Actual: KURS } \\
\text { Sample: 1997:06 1999:12 } \\
\text { Include observations: } 16\end{array}$} \\
\hline Root Mean Squared Error & 5352.285 \\
\hline Mean Absolute Error & 4073.550 \\
\hline Mean Abs. Percent Error & 41.65763 \\
\hline Theil Inequality Coefficien & \\
\hline Bias Proportion & 0.572912 \\
\hline Variance Proportion & 0.410126 \\
\hline & \\
\hline
\end{tabular}

IV. Mengukur Ekspektasi Inflasi Dengan Kurs Rp/USD Backward Looking

Dependent Variable: CPI
Method: Least Squares
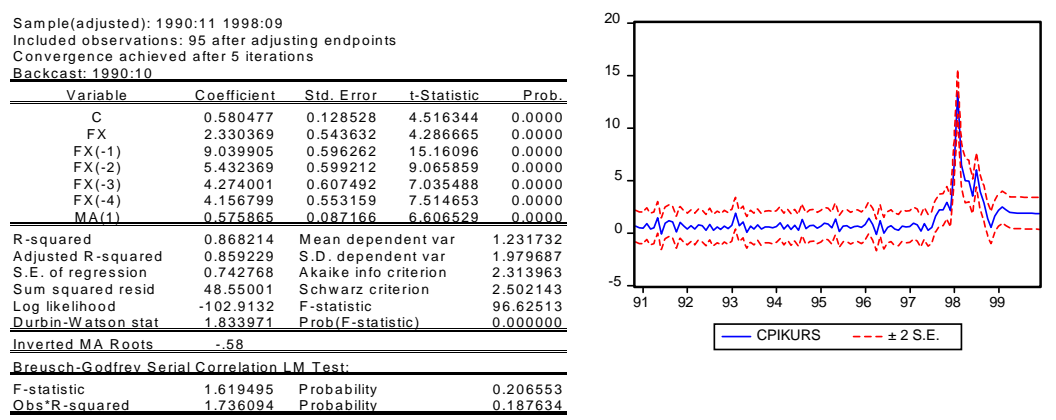

Forecast: CPIKUR

Actual: CPI 1 : 199: 12
Sample: $1990: 11$ Include observations: 15

Root Mean Squared Error $\quad 0.714880$

Mean Absolute Error $\quad 0.518561$

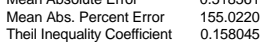

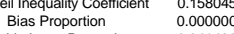

$\begin{array}{ll}\text { Variance Proportion } & 0.04449 \\ \text { Covariance Proportion } & 0.958502\end{array}$ 
V. Mengukur Ekspektasi Inflasi Dengan Kredibilitas Kebijakan Disinflasi Dependent Variable: $C P$ I

Method: Least Squares
Date: $10 / 20 / 98$ Time: 20.53

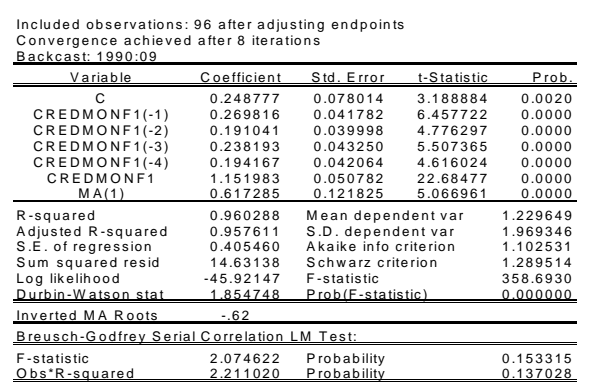

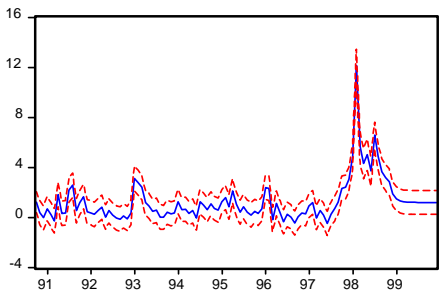

- CPICREDIBLE --- \pm 2 S.E.

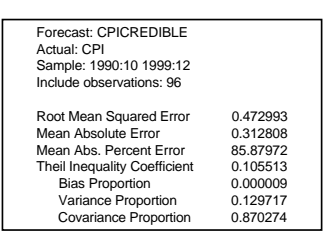

VI. Mengukur Ekspektasi Inflasi Forward Looking

\section{Ekspektasi di Pasar Valas}

Dependent Variable: CPI Method: Least Squares

Sample: 1990:06 1998:09

ved after 8 iterations

Backcast: 1990:05

\begin{tabular}{lrllr}
\hline \hline \multicolumn{1}{c}{ Variable } & Coefficient & Std. Error & t-Statistic & Prob. \\
\hline MSWAP & 0.550246 & 0.430830 & 1.277179 & 0.2046 \\
MA(1) & 0.719070 & 0.381734 & 1.883692 & 0.0626 \\
\hline \hline R-squared & 0.736816 & 0.069166 & 10.65293 & 0.0000 \\
Adjusted R-squared & 0.484538 & Mean dependent var & 1.210365 \\
S.E. of regression & 0.473910 & S.D. dependent var & 1.932518 \\
Sum squared resid & 1.401695 & Akaike info criterion & 3.542782 \\
Log likelihood & 190.5806 & Schwarz criterion & 3.620937 \\
Durbin-Watson stat & -174.1491 & F-statistic & 45.59043 \\
\hline Inverted MA Roots & 1.614613 & Prob(F-statistic) & 0.000000 \\
\hline Breusch-Godfrey Serial Correlation LM Test: & \\
\hline \hline F-statistic & -.74 & & \\
Obs*R-squared & 7.071280 & Probability & 0.009179 \\
\hline \hline
\end{tabular}

\section{Ekspektasi di Pasar Keuangan}

Dependent Variable: CPI

Sample: 1990:06 1998:09

Convergence achieved after 8 iterations

Backcast: 1990:05

\begin{tabular}{|c|c|c|c|c|}
\hline Variable & Coefficient & Std. Error & $\mathrm{t}$-Statistic & Prob. \\
\hline $\begin{array}{c}\mathrm{C} \\
\text { MYIELD } \\
\text { MA(1) }\end{array}$ & & $\begin{array}{l}0.212049 \\
0.207733 \\
0.081762 \\
\end{array}$ & $\begin{array}{l}4.229941 \\
5.474462 \\
7.460785 \\
\end{array}$ & $\begin{array}{l}0.0001 \\
0.0000 \\
0.0000\end{array}$ \\
\hline $\begin{array}{l}\text { R-squared } \\
\text { Adjusted R-squared } \\
\text { S.E. of regression } \\
\text { Sum squared resid } \\
\text { Log likelihood } \\
\text { Durbin-Watson stat } \\
\end{array}$ & $\begin{array}{r}0.578544 \\
0.569854 \\
1.267452 \\
155.8242 \\
-164.0718 \\
2.060648 \\
\end{array}$ & \multicolumn{2}{|c|}{$\begin{array}{l}\text { Mean dependent var } \\
\text { S.D. dependent var } \\
\text { Akaike info criterion } \\
\text { Schwarz criterion } \\
\text { F-statistic } \\
\text { Prob(F-statistic) }\end{array}$} & $\begin{array}{l}1.210365 \\
1.932518 \\
3.341435 \\
3.419590 \\
66.57722 \\
0.000000 \\
\end{array}$ \\
\hline \multirow{2}{*}{\multicolumn{5}{|c|}{$\begin{array}{lc}\text { Inverted MA Roots } & -.61 \\
\text { Breusch-Godfrey Serial Correlation LM Test }\end{array}$}} \\
\hline & & & & \\
\hline $\begin{array}{l}\text {-statistic } \\
\text { bss } \text { bs }^{*} \mathrm{~s} q \mathrm{~s}\end{array}$ & $\begin{array}{l}0.306005 \\
0.317549 \\
\end{array}$ & $\begin{array}{l}\text { Probability } \\
\text { Probability }\end{array}$ & & $\begin{array}{l}0.581428 \\
0.573085 \\
\end{array}$ \\
\hline
\end{tabular}

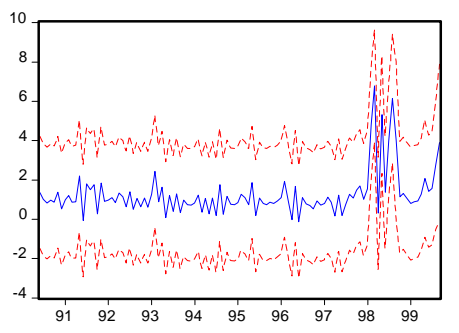

\begin{tabular}{ll} 
Forecast: CPISWAP & \\
Actual: CPI & \\
Sample: 1990:06 1999:09 \\
Include observations: 100 \\
\\
Root Mean Squared Error & 1.380509 \\
Mean Absolute Error & 0.780994 \\
Mean Abs. Percent Error & 227.852 \\
Theil Inequality Coefficient & 0.350817 \\
Bias Proportion & 0.000001 \\
Variance Proportion & 0.322227 \\
Covariance Proportion & 0.677772 \\
\hline
\end{tabular}

- CPISWAP --- \pm 2 S.E.

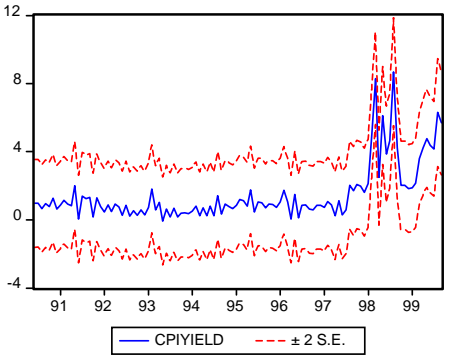

Forecast: CPIYIELD
Actual: CPI

Sample: 1990:06 1999:09

Root Mean Squared Error 1.248296 Mean Absolute Error $\quad 0.712391$ Theil Inequality Coefficient $\quad 0.300050$ $\begin{array}{cc}\text { Theil Inequality Coefficient } & 0.30005 \\ \text { Bias Proportion } & 0.00000\end{array}$ $\begin{array}{ll}\text { Variance Proportion } & 0.144799 \\ \text { Covariance Proportion } & 0.855199\end{array}$ 
VII. Uji Granger Causality antara Inflasi dan Forward Rate Rp/USD

\section{Sepanjang Krisis}

\begin{tabular}{|c|c|c|}
\hline Null Hypothesis: & F-Statistic & Probability \\
\hline SWAP does not Granger Cause & $\overline{\mathrm{ANCPI}}$ & $\begin{array}{ll}6.31689 & 0.01387\end{array}$ \\
\hline ANCPI does not Granger Cause & SWAP & $46.2037 \quad 1.4 \mathrm{E}-09$ \\
\hline \multicolumn{3}{|l|}{ Lags: 2} \\
\hline Null Hypothesis: & F-Statistic & Probability \\
\hline SWAP does not Granger Cause & $\overline{\mathrm{ANCPI}}$ & 0.886590 .41602 \\
\hline ANCPI does not Granger Cause & SWAP & $20.7925 \quad 5.2 \mathrm{E}-08$ \\
\hline \multicolumn{3}{|l|}{ Lags: 3} \\
\hline Null Hypothesis: & F-Statistic & Probability \\
\hline SWAP does not Granger Cause & ANCPI & $3.46644 \quad 0.02013$ \\
\hline ANCPI does not Granger Cause & SWAP & $18.5885 \quad 3.4 \mathrm{E}-09$ \\
\hline \multicolumn{3}{|l|}{ Lags: 4} \\
\hline Null Hypothesis: & F-Statistic & Probability \\
\hline SWAP does not Granger Cause & ANCPI & $4.95316 \quad 0.00134$ \\
\hline ANCPI does not Granger Cause & SWAP & $35.5097 \quad 1.3 E-16$ \\
\hline \multicolumn{3}{|l|}{ Lags: 5} \\
\hline Null Hypothesis: & F-Statistic & Probability \\
\hline SWAP does not Granger Cause & ANCPI & $4.45891 \quad 0.00135$ \\
\hline ANCPI does not Granger Cause & SWAP & $26.0828 \quad 6.2 \mathrm{~F}-15$ \\
\hline \multicolumn{3}{|l|}{ Lags: 6} \\
\hline Null Hypothesis: & F-Statistic & Probability \\
\hline SWAP does not Granger Cause & ANCPI & $2.71644 \quad 0.01992$ \\
\hline ANCPI does not Granger Cause & SWAP & $20.7315 \quad 1.0 \mathrm{E}-13$ \\
\hline \multicolumn{3}{|l|}{ Lags: 7} \\
\hline Null Hypothesis: & F-Statistic & Probability \\
\hline SWAP does not Granger Cause & $\overline{\mathrm{ANCPI}}$ & $2.47840 \quad 0.02540$ \\
\hline ANCPI does not Granger Cause & SWAP & $19.7172 \quad 5.6 \mathrm{E}-14$ \\
\hline \multicolumn{3}{|l|}{ Lags: 8} \\
\hline Null Hypothesis: & F-Statistic & Probability \\
\hline SWAP does not Granger Cause & $\overline{\mathrm{ANCPI}}$ & $2.83510 \quad 0.00940$ \\
\hline ANCPI does not Granger Cause & SWAP & $16.8733 \quad 4.5 \mathrm{E}-13$ \\
\hline \multicolumn{3}{|l|}{ Lags: 9} \\
\hline Null Hypothesis: & F-Statistic & Probability \\
\hline SWAP does not Granger Cause & ANCPI & $2.36934 \quad 0.02301$ \\
\hline ANCPI does not Granger Cause & SWAP & $17.3929 \quad 1.0 \mathrm{E}-13$ \\
\hline Lags: 10 & & \\
\hline Null Hypothesis: & F-Statistic & Probability \\
\hline SWAP does not Granger Cause & ANCPI & $2.69482 \quad 0.00892$ \\
\hline ANCPI does not Granger Cause & SWAP & $14.9881 \quad 1.2 \mathrm{E}-12$ \\
\hline Lags: 11 & & \\
\hline Null Hypothesis: & F-Statistic & Probability \\
\hline SWAP does not Granger Cause & ANCPI & $2.16061 \quad 0.03081$ \\
\hline ANCPI does not Granger Cause & SWAP & $13.3469 \quad 8.4 \mathrm{E}-12$ \\
\hline Lags: 12 & & \\
\hline Null Hypothesis: & F-Statistic & Probability \\
\hline SWAP does not Granger Cause & $\overline{\mathrm{ANCPI}}$ & $2.07661 \quad 0.03564$ \\
\hline ANCPI does not Granger Cause & SWAP & $11.5781 \quad 9.6 \mathrm{E}-11$ \\
\hline
\end{tabular}


2. Sebelum Krisis

\begin{tabular}{|c|c|c|}
\hline Null Hypothesis: & F-Statistic & Probability \\
\hline SWAP does not Granger Cause & ANCPI & 1.526560 .22082 \\
\hline ANCPI does not Granger Caus & SWAP & $0.04721 \quad 0.82864$ \\
\hline \multicolumn{3}{|l|}{ Lags: 2} \\
\hline Null Hypothesis: & F-Statistic & Probability \\
\hline SWAP does not Granger Cause & $\overline{\mathrm{ANCPI}}$ & $2.14832 \quad 0.12477$ \\
\hline ANCPI does not Granger Caus & SWAP & $\begin{array}{ll}1.04455 & 0.35759 \\
\end{array}$ \\
\hline \multicolumn{3}{|l|}{ Lags: 3} \\
\hline Null Hypothesis: & F-Statistic & Probability \\
\hline SWAP does not Granger Cause & ANCPI & $4.02132 \quad 0.01108$ \\
\hline ANCPI does not Granger Caus & SWAP & $0.95555 \quad 0.41934$ \\
\hline \multicolumn{3}{|c|}{ Lags: 4} \\
\hline Null Hypothesis: & F-Statistic & Probability \\
\hline SWAP does not Granger Cause & ANCPI & $2.69675 \quad 0.03908$ \\
\hline ANCPI does not Granger caus & SWAP & $0.46232 \quad 0.76307$ \\
\hline \multicolumn{3}{|c|}{ Lags: 5} \\
\hline Null Hypothesis: & F-Statistic & Probability \\
\hline SWAP does not Granger Cause & ANCPI & 2.491290 .04143 \\
\hline ANCPI does not Granger Caus & SWAP & $0.52412 \quad 0.75701$ \\
\hline \multicolumn{3}{|l|}{ Iags: 6} \\
\hline Null Hypothesis: & F-Statistic & Probability \\
\hline SWAP does not Granger Cause & ANCPI & $\begin{array}{ll}1.87108 & 0.10272\end{array}$ \\
\hline ANCPI does not Granger Cause & SWAP & $0.39039 \quad 0.88202$ \\
\hline \multicolumn{3}{|l|}{ Lags: 7} \\
\hline Null Hypothesis: & F-Statistic & Probability \\
\hline SWAP does not Granger Cause & ANCPI & 1.490850 .19164 \\
\hline ANCPI does not Granger Caus & SWAP & $0.48897 \quad 0.83818$ \\
\hline \multicolumn{3}{|l|}{ Lags: 8} \\
\hline Null Hypothesis: & F-Statistic & Probability \\
\hline SWAP does not Granger Cause & ANCPI & 1.467980 .19392 \\
\hline ANCPI does not Granger Caus & SWAP & $\begin{array}{ll}1.31446 & 0.25923 \\
\end{array}$ \\
\hline \multicolumn{3}{|l|}{ Lags: 9} \\
\hline Null Hypothesis: & F-Statistic & Probability \\
\hline SWAP does not Granger Cause & ANCPI & $1.27529 \quad 0.27652$ \\
\hline ANCPI does not Granger Caus & SWAP & $1.75684 \quad 0.10382$ \\
\hline ags: 10 & & \\
\hline Null Hypothesis: & F-Statistic & Probability \\
\hline SWAP does not Granger Cause & ANCPI & $1.33496 \quad 0.24411$ \\
\hline ANCPT does not Granger Causs & SWAP & $1.81888 \quad 0.08676$ \\
\hline ags: 11 & & \\
\hline Null Hypothesis: & F-Statistic & Probability \\
\hline SWAP does not Granger Cause & ANCPI & 1.362030 .22939 \\
\hline ANCPI does not Granger Caus & SWAP & $1.77294 \quad 0.09308$ \\
\hline ags: 12 & & \\
\hline Null Hypothesis: & F-Statistic & Probability \\
\hline SWAP does not Granger Cause & ANCPI & $1.24285 \quad 0.29361$ \\
\hline ANCPI does not Granger Caus & SWAP & $1.51623 \quad 0.16350$ \\
\hline
\end{tabular}




\section{Metodologi Neural Network}

Neural network adalah alat analisa yang mereplikasi proses belajar otak manusia. Asumsi yang mendasari analisa neural network adalah bounded rationality para pelaku ekonomi, yaitu fakta bahwa kompleksitas lingkungan tidak dapat sepenuhnya dikalkulasi oleh rasionalitas. Akibat dari bounded rationality tersebut adalah kecemasan jika lingkungan dipenuhi oleh ketidakpastian yang kemudian diterjemahkan menjadi kepanikan (frentic euphoria). Analisa dengan neural network mencoba menangkap gejala-gejala non-linier tersebut.

Desain analisa dengan neural network adalah sebagai berikut ${ }^{23}$ :

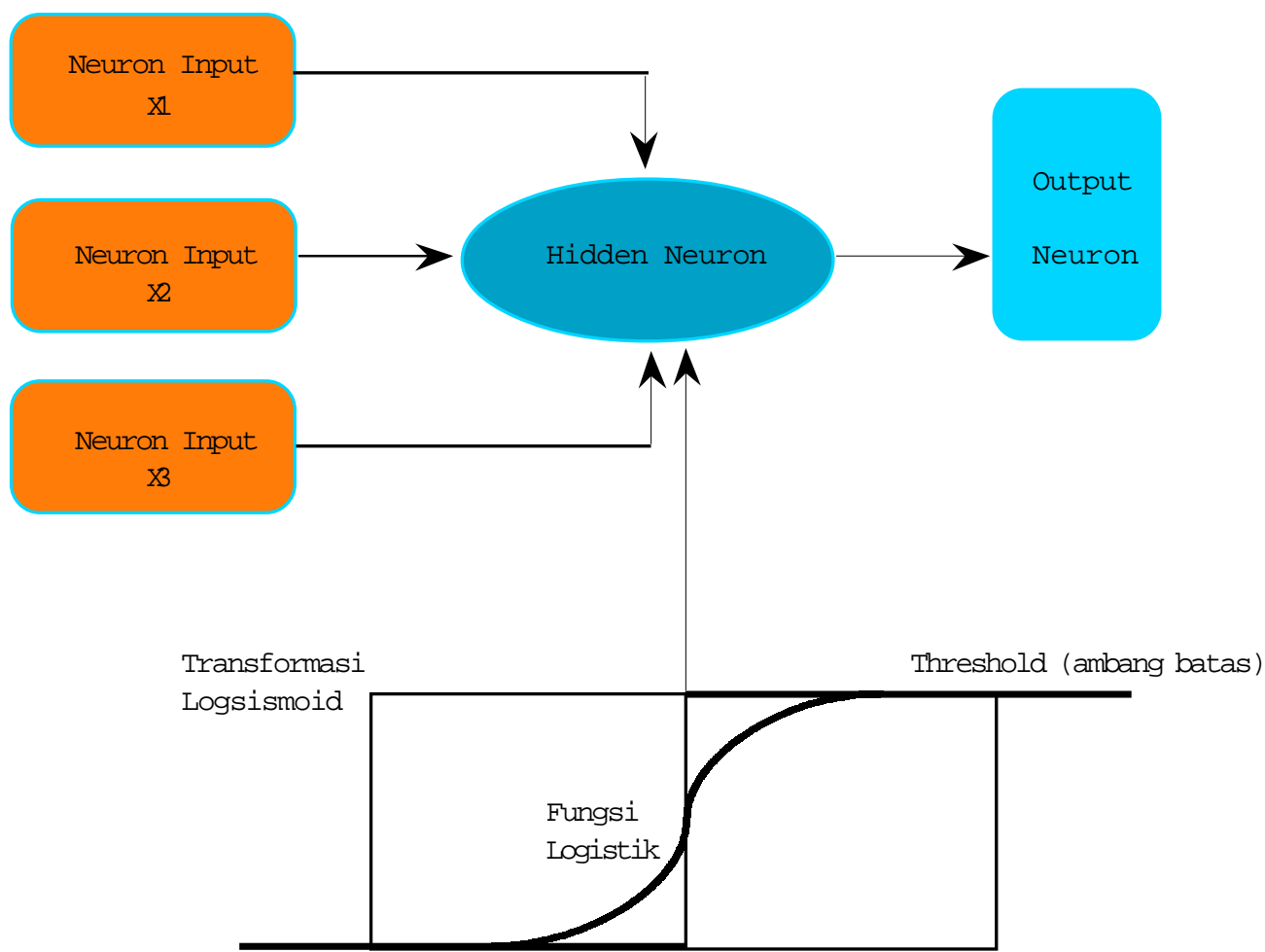

Penjelasan dari desain diatas adalah sebagai berikut:

- Neuron-neuron input, x1, x2, x3, dan seterusnya adalah kombinasi linear dengan kofisien dan bobot tertentu yang diperoleh dari estimasi secara linier. Dalam paper ini neuron-

23 Disadur dari : McNelis, Paul D. Money Demand, Finacial Distress, and Monetary Policy in Indonesia. Georgetown University, Department of Economics, April 1998. Unpublished research paper. 
neuron input adalah masing-masing ekspektasi inflasi yang diperoleh melalui estimasi linier, yaitu eskpektasi inflasi karena: (1) inertia, (2) ekspektasi kurs Ro/USD, dan (3) kredibilitas kebijakan disinflasi pemerintah, untuk ekspektasi yang terbentuk secara backward looking. Untuk input neuron yang berasal dari ekspektasi inflasi yang terbentuk secara forward looking adalah ekpektasi inflasi di pasar keuangan dan di pasar valas. Sehingga, terdapat lima input neuron dalam desain neural network.

- Neuron-neuron input diatas selanjutnya dimasukkan kedalam hidden neuron dimana terjadi transfomasi logsismoid. Transformasi ini dimungkinkan oleh proses logistic squashing untuk membentuk fungsi logsismoid sebagaimana yang diilustrasikan diatas.

- Setelah melalui proses transformasi, neuron input kemudian dikombinasikan dengan neuron output, yaitu unweighted average dari input-input neuron. Dalam pengkombinasian ini berlangsung proses backpropagation leaming, yaitu proses belajar untuk menghasilkan persamaan dengan error terendah. Secara ekonomis proses belajar tersebut mengakomodir perilaku "Sargeant's economic agent" yang dalam pilihan-pilihan perilakunya terikat oleh bounded rationality ${ }^{24}$. Langkah-langkah dalam proses backpropagation leaming tersebut adalah sebagai berikut ${ }^{25}$ :

$\Rightarrow$ Penentuan bobot awal dengan mengambil suatu sampel test set yang memberi gambaran mengenai karakteristik awal hubungan antara neuron input dan output.

$\Rightarrow$ Melakukan training terhadap seluruh observasi sampai tercapai error terendah.

$\Rightarrow$ Melakukan pembobotan ulang berdasarkan bobot-bobot yang diperoleh dari training.

$\Rightarrow$ Menguji fitress dari persamaan.

24 Sargent, Thomas J. Bounded Rationality in Macroeconomics. Oxford University Press, New York, 1993. 25 Diproses dengan software NeuroShell 1.1. 